\title{
Evidence for a stepwise program of extrathymic T cell development within the human tonsil
}

\author{
Susan McClory,,$^{1,2}$ Tiffany Hughes, ${ }^{2}$ Aharon G. Freud, ${ }^{3}$ Edward L. Briercheck, ${ }^{1,2}$ \\ Chelsea Martin, ${ }^{4}$ Anthony J. Trimboli, 4 Jianhua Yu,5,6 Xiaoli Zhang,6,7 \\ Gustavo Leone, ${ }^{1,2,4,6,8}$ Gerard Nuovo, ${ }^{9}$ and Michael A. Caligiuri'1,2,5,6,8
}

\begin{abstract}
${ }^{1}$ Medical Scientist Training Program and 2 Integrated Biomedical Sciences Graduate Program, The Ohio State University, Columbus, Ohio, USA. ${ }^{3}$ Department of Pathology, Stanford University School of Medicine, Palo Alto, California, USA. ${ }^{4}$ Department of Molecular Genetics, ${ }^{5}$ Division of Hematology, Department of Internal Medicine, ${ }^{6}$ Comprehensive Cancer Center and Arthur G. James Cancer Hospital and Richard J. Solove Research Institute, ${ }^{7}$ Center for Biostatistics, ${ }^{8}$ Department of Molecular Virology, Immunology, and Medical Genetics, and ${ }^{9}$ Department of Pathology, The Ohio State University, Columbus, Ohio, USA.
\end{abstract}

\begin{abstract}
The development of a broad repertoire of $\mathrm{T}$ cells, which is essential for effective immune function, occurs in the thymus. Although some data suggest that $T$ cell development can occur extrathymically, many researchers remain skeptical that extrathymic $T$ cell development has an important role in generating the $T$ cell repertoire in healthy individuals. However, it may be important in the setting of poor thymic function or congenital deficit and in the context of autoimmunity, cancer, or regenerative medicine. Here, we report evidence that a stepwise program of $T$ cell development occurs within the human tonsil. We identified 5 tonsillar $T$ cell developmental intermediates: (a) $\mathrm{CD} 34^{+} \mathrm{CD} 38^{\mathrm{dim}} \mathrm{Lin}^{-}$cells, which resemble multipotent progenitors in the bone marrow and thymus; (b) more mature $\mathrm{CD} 34^{+} \mathrm{CD} 38^{\text {bright }} \mathrm{Lin}^{-}$cells; (c) $\mathrm{CD} 34^{+} \mathrm{CD} 1 \mathrm{a}^{+} \mathrm{CD} 11 \mathrm{c}^{-}$cells, which resemble committed $T$ cell lineage precursors in the thymus; (d) $\mathrm{CD} 34^{-} \mathrm{CD} 1 \mathrm{a}^{+} \mathrm{CD} 3^{-} \mathrm{CD} 11 \mathrm{c}^{-}$cells, which resemble $\mathrm{CD}^{+} \mathrm{CD}^{+}$doublepositive $\mathrm{T}$ cells in the thymus; and (e) $\mathrm{CD34}-\mathrm{CD} 1 \mathrm{a}^{+} \mathrm{CD}^{+} \mathrm{CD} 11 \mathrm{c}^{-}$cells. The phenotype of each subset closely resembled that of its thymic counterpart. The last 4 populations expressed RAG1 and PTCRA, genes required for TCR rearrangement, and all 5 subsets were capable of ex vivo $\mathrm{T}$ cell differentiation. $\mathrm{TdT}^{+}$cells found within the tonsillar fibrous scaffold expressed CD34 and/or CD1a, indicating that this distinct anatomic region contributes to pre- $T$ cell development, as does the subcapsular region of the thymus. Thus, we provide evidence of a role for the human tonsil in a comprehensive program of extrathymic $T$ cell development.
\end{abstract}

\section{Introduction}

The development of human $\mathrm{T}$ cells can be divided into discrete stages, ranging from that for multipotent progenitors to that for naive T cells. The expression of CD4 and/or CD8 divides thymocytes into the categories of double-negative, immature single-positive, double-positive (DP), and single-positive cells $(1,2)$. Based on TCR gene rearrangements and differentiation capabilities, double-negative thymocytes are divided into the least mature $\mathrm{CD} 34^{+} \mathrm{CD} 38^{\mathrm{dim}} \mathrm{CD} 1 \mathrm{a}^{-}$cells and the progressively more mature $\mathrm{CD} 34^{+} \mathrm{CD} 38^{\text {bright }} \mathrm{CD} 1 \mathrm{a}^{-}$and $\mathrm{CD} 34^{+} \mathrm{CD} 1 \mathrm{a}^{+}$cells $(2,3) . \mathrm{CD} 34^{+} \mathrm{CD} 1 \mathrm{a}^{+}$ thymocytes acquire CD4 and then CD8 as they lose CD34, to become CD34- DP cells. Finally, $\mathrm{CD}^{+}$DP thymocytes lose either CD4 or CD8 to become single-positive naive T cells (1).

Development of a healthy $\mathrm{T}$ cell repertoire is dependent on a functional thymus. However, the potential for human extrathymic lymphoid tissue to augment $\mathrm{T}$ cell development is poorly understood but may be important in the setting of poor thymic function or congenital deficit. Previous reports of extrathymic T cell development in humans have relied primarily on the identification of cells expressing genes associated with TCR loci rearrangement in the intestine or bone marrow. Indeed, $\mathrm{CD} 7^{+} \mathrm{CD} 10^{+}$cells expressing pre-TCR $\alpha(P T C R A)$, recombination activating gene 1 (RAG1), and $R A G 2$ mRNA and varying levels of TCRB gene recombination have

Conflict of interest: The authors have declared that no conflict of interest exists. Citation for this article: J Clin Invest. 2012;122(4):1403-1415. doi:10.1172/JCI46125. been identified in postnatal bone marrow (4). However, recent reports were unable to identify $\mathrm{CD} 34^{+} \mathrm{CD} 45 \mathrm{RA}{ }^{+} \mathrm{CD} 7^{+} \mathrm{CD} 10^{+}$ cells in the same tissue $(5,6)$, indicating that it is unlikely that the $\mathrm{CD} 7^{+} \mathrm{CD} 10^{+}$bone marrow cells identified include early $\mathrm{CD} 34^{+}$ pre-T cells. Similarly, $\mathrm{CD}^{+} \mathrm{CD}^{+}{ }^{+} \mathrm{CD} 3^{-}$cells have been identified in neonatal intestine, and PTCRA, TdT (also known as DNTT), and RAG2 mRNA can be detected in whole lysates of these tissues (7); yet, whether or not $\mathrm{CD} 34^{+} \mathrm{T}$ cell progenitors reside there is unclear. Finally, several reports have identified $\mathrm{TdT}^{+}$cells in extrafollicular zones of the human tonsil near fibrous scaffolding (8-11). However, little is known about the function or phenotype of these cells. Thus, no complete program of human $\mathrm{T}$ cell development has been described in an extrathymic tissue.

Human tonsils and lymph nodes contain resident CD34+ cells (12, 13). However, to date, the $\mathrm{CD} 34^{+}$compartment of human secondary lymphoid tissue has been characterized primarily by its ability to contribute to NK cell development. Specifically, it has been divided into 2 maturational stages of NK cell intermediate, distinguished by the expression of CD117. Stage 1 pro-NK cells are minimally defined as $\mathrm{CD} 34^{+} \mathrm{CD} 117^{-}$, whereas stage 2 pre-NK cells are defined as $\mathrm{CD} 34^{+} \mathrm{CD} 117^{+}$. Each of these $\mathrm{CD} 34^{+}$populations has the differentiation potential for T cells, DCs, and NK cells (13). However, the minimal definitions of stage 1 and 2 cells do not account for the immense phenotypic heterogeneity within each population (14). Whether stage 1 or 2 NK precursors contain distinct subpopulations, each capable of giving rise to other hematopoietic lineages, is unknown. 

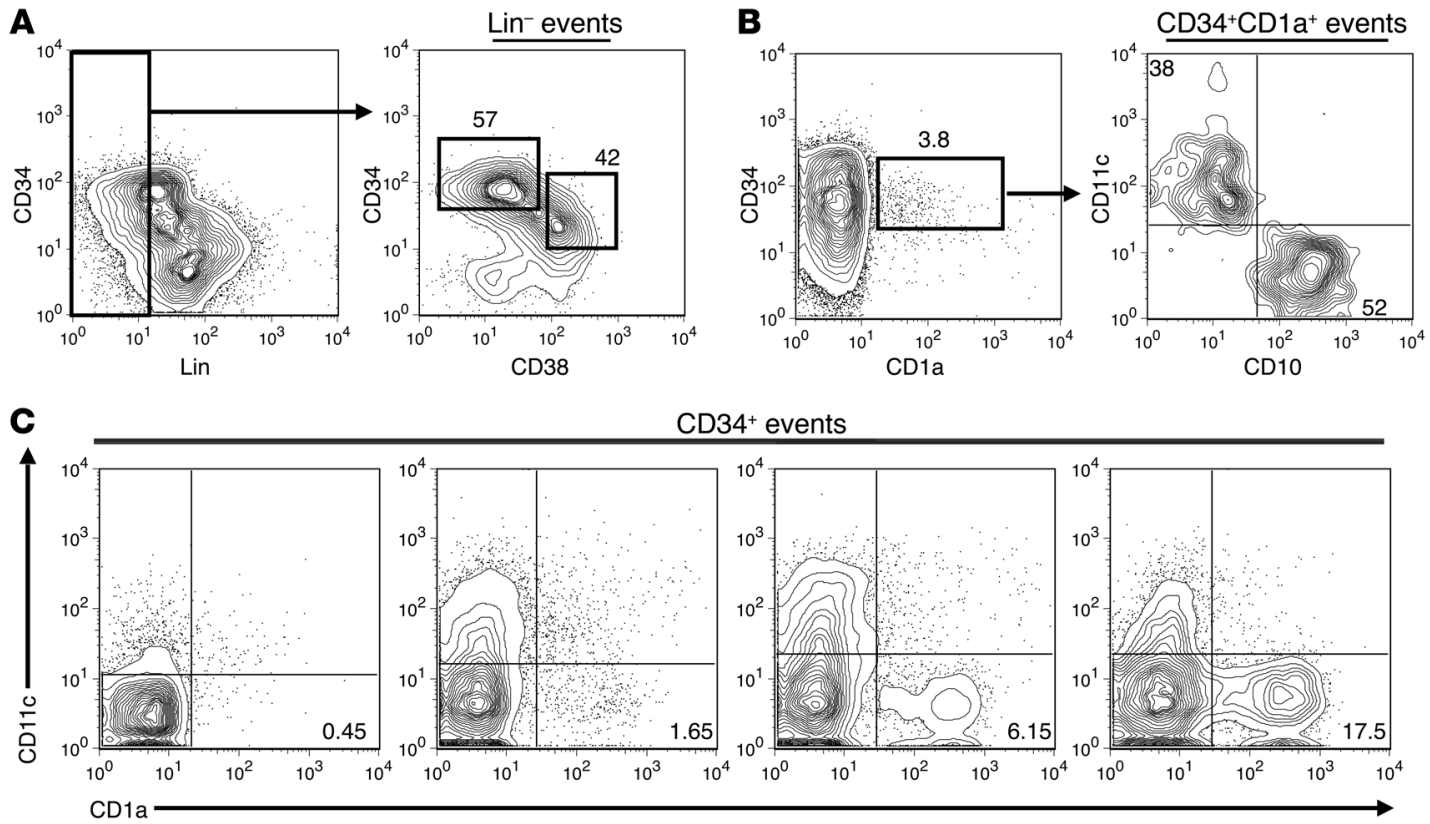

\section{Figure 1}

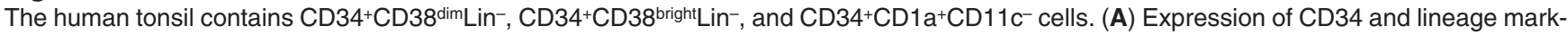
ers (CD11c, BDCA-2, CD117, CD161, CD19, CD3, CD1a) on CD34-enriched tonsillar cells (left). Total lymphocytes were gated on Lin- events and analyzed for their expression of CD34 and CD38 (right). The number above each gate indicates the mean percentage of CD34+ cells falling within that gate. (B) Expression of CD1a on CD34-enriched tonsillar cells (left). The number above each gate indicates the mean percentage of $\mathrm{CD} 34^{+}$cells falling within that gate. Events were gated on CD34+CD1a+ cells and analyzed for their coexpression of CD10 and CD11c (right). The number within the top left and bottom right quadrants represents the mean percentage of CD34+CD1a+cells that are defined as either CD11 ${ }^{+}$ or $\mathrm{CD} 10^{+}$, respectively. (C) The percentage of $\mathrm{CD} 34^{+}$cells that are defined as $\mathrm{CD} 34^{+} \mathrm{CD} 1 \mathrm{a}^{+} \mathrm{CD} 11 \mathrm{c}^{-}$in 4 representative human pediatric tonsils. Plots are gated on total CD34+ cells. Numbers in the bottom right quadrant indicate the percentage of CD34+ cells that are CD1a+CD11 ${ }^{-}$in that particular donor. All data are from a representative tonsil of $(\mathbf{A}) 3,(B) 4$, or (C) 24 individual donors.

Here, we provide evidence for a role of human tonsil in a stepwise program of extrathymic $\mathrm{T}$ cell development. We identify 5 $T$ cell developmental intermediates within the tonsil, each one with $T$ cell differentiation potential, as well as a phenotype closely resembling the corresponding populations in the thymus. Furthermore, we discovered that the $\mathrm{TdT}^{+}$cells found near the fibrous scaffold of the tonsil express CD34 and/or the pre-T cell marker CD1a, indicating that distinct anatomical regions of the tonsil contribute to the earliest stages of extrathymic T cell development. Finally, we demonstrate that $\mathrm{CD} 34^{+} /-\mathrm{CD} 1 \mathrm{a}^{+} \mathrm{CD} 11 \mathrm{c}^{-}$tonsillar and thymic cells retain both $\mathrm{T}$ cell and NK cell developmental potential.

\section{Results}

$\mathrm{CD}^{2} 4^{+} \mathrm{CD} 38^{\mathrm{dim}} \mathrm{Lin}^{-}, \mathrm{CD} 34^{+} \mathrm{CD} 38^{\text {bright }} \mathrm{Lin}^{-}$, and $\mathrm{CD} 34^{+} \mathrm{CD} 1 \mathrm{a}^{+} \mathrm{CD} 11 \mathrm{C}^{-}$ cells reside within the buman tonsil. Dim expression of CD38 on $\mathrm{CD} 4^{+}$cells identifies multipotent progenitor populations in the bone marrow, thymus, and umbilical cord blood, and increased expression of CD38 on $\mathrm{CD} 4^{+}$cells is associated with differentiation $(1,3,15-17)$. Analyzing magnetically enriched CD34+ tonsillar cells for the expression of CD34 and CD38, together with the lineage (Lin) antigens CD3, CD19, CD117, CD161, BDCA-2, CD11c, and CD1a, revealed that the human pediatric tonsil contains a population of $\mathrm{CD} 34^{+} \mathrm{CD} 38^{\mathrm{dim}} \mathrm{Lin}^{-}$cells as well as a $\mathrm{CD} 34^{+} \mathrm{CD} 38^{\text {bright }} \mathrm{Lin}^{-}$subset. In general, the $\mathrm{CD} 34^{+} \mathrm{CD} 38^{\mathrm{dim}}$ subset tended to express higher surface density of CD34 than the $\mathrm{CD} 34^{+} \mathrm{CD} 38^{\text {bright }}$ population (Figure $1 \mathrm{~A}$ ), suggesting that the human tonsil may contain a multipotent hematopoietic progenitor minimally defined as $\mathrm{CD} 34^{+} \mathrm{CD} 38^{\mathrm{dim}} \mathrm{Lin}^{-}$as well as a more mature $\mathrm{CD} 34^{+} \mathrm{CD} 38^{\text {bright }} \mathrm{Lin}^{-}$population.

Commitment to the $\mathrm{T}$ cell lineage in the human thymus is associated with the acquisition of $\mathrm{CD} 1 \mathrm{a}$ on $\mathrm{CD} 34^{+} \mathrm{CD} 10^{+} \mathrm{CD} 7^{+}$thymocytes (1). However, CD1a expression is also canonically associated with DC populations $(18,19)$. Within the human tonsil there was a small but consistent population of $\mathrm{CD} 34^{+} \mathrm{CD} 1 \mathrm{a}^{+}$lymphocytes (Figure 1B), which lacked CD117, CD161, BDCA-2, CD14, CD19, and CD3 (data not shown). However, when analyzed for the expression of CD10 and the DC marker CD11c, CD34 $4^{+} \mathrm{CD} 1 \mathrm{a}^{+}$ tonsillar cells expressed either CD11c or CD10 (Figure 1B). Substantial donor-to-donor variation exists in the relative size of the $\mathrm{CD} 34^{+} \mathrm{CD} 1 \mathrm{a}^{+} \mathrm{CD} 11 \mathrm{c}^{-}$subset in the tonsil (Figure $1 \mathrm{C}$ ). In 24 pediatric donors, $\mathrm{CD} 34^{+} \mathrm{CD} 1 \mathrm{a}^{+} \mathrm{CD} 11 \mathrm{c}^{-}$tonsillar cells constituted between $0.15 \%-19.4 \%$ of the total CD $34^{+}$population (mean, $3.82 \% \pm 1.06 \%$; median, $1.47 \%)$. No statistical correlation was found between the percentage of $\mathrm{CD} 34^{+} \mathrm{CD} 1 \mathrm{a}^{+} \mathrm{CD} 11 \mathrm{c}^{-}$cells and the age (1-16 years) or gender of the donor.

Tonsillar CD $34^{+} \mathrm{CD} 38^{\text {dim }} \mathrm{Lin}^{-}, \mathrm{CD} 34^{+} \mathrm{CD} 38^{\text {bright }} \mathrm{Lin}^{-}$, and $C D 34^{+} C D 1 a^{+} C D 11 c^{-}$cells phenotypically resemble the earliest stages of thymocyte development. To determine whether or not the $\mathrm{CD} 34^{+} \mathrm{CD} 38^{\mathrm{dim}} \mathrm{Lin}^{-}, \mathrm{CD} 34^{+} \mathrm{CD} 38^{\text {bright }} \mathrm{Lin}^{-}$, and $\mathrm{CD} 34^{+} \mathrm{CD} 1 \mathrm{a}^{+} \mathrm{CD} 11 \mathrm{c}^{-}$cells identified in the tonsil represent extrathymic $\mathrm{T}$ cell precursors similar to those found in the thymus, each subset from tonsil and thymus was extensively pheno- 
typed by flow cytometry (Figure 2). In both the tonsil and thymus, CD 34 ${ }^{+}$CD 38 ${ }^{\text {dim }}$ Lin $^{-}$cells expressed CD10, CD33, CD45RA, and HLA-DR as well as variable levels of CD25 and intracellular TdT. Similarly, CD $34^{+} \mathrm{CD} 38^{\mathrm{dim}} \mathrm{Lin}^{-}$cells from both tissues lacked expression of CD4, CD8, CD56, and CD116 (Figure 2). However, there are distinct differences between tonsillar and thy-

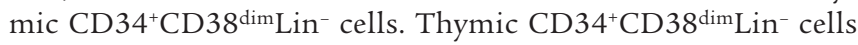
expressed CD2 and most expressed CD5 and CD7, while a small fraction expressed the IL-7 receptor $\alpha$ (CD127) (Figure 2B). The same cells in the tonsil lacked CD2 and CD127, and only a small fraction expressed CD5 or CD7 (Figure 2).

CD $34^{+} \mathrm{CD} 38^{\text {bright }}$ Lin $^{-}$cells from the tonsil and thymus are similar in that both expressed CD2, CD10, and low levels of CD45RA. Similarly, both populations lacked expression of CD4, CD8, CD56, and CD116. However, CD 34 ${ }^{+} \mathrm{CD} 38^{\text {bright }}$ Lin $^{-}$cells from the tonsil expressed variable levels of CD7 and CD5, and only small amounts of intracellular CD $3 \varepsilon$ (icCD3e), whereas those from the thymus were all $\mathrm{CD}^{+} \mathrm{CD} 5^{+} \mathrm{icCD} 3 \varepsilon^{+}$. Furthermore, tonsil CD $34^{+} \mathrm{CD} 38^{\text {bright }} \mathrm{Lin}^{-}$cells expressed $\mathrm{CD} 33$ and variable levels of HLA-DR, which were largely absent on the same cells from the thymus (Figure 2). Despite the differences seen in $\mathrm{CD} 4^{+} \mathrm{CD} 38^{\text {bright }} \mathrm{Lin}^{-}$cells, each subset represents a phenotype that is in many ways intermediate between $\mathrm{CD} 34^{+} \mathrm{CD} 38^{\mathrm{dim}} \mathrm{Lin}^{-}$cells and $\mathrm{CD} 34^{+} \mathrm{CD} 1 \mathrm{a}^{+} \mathrm{CD} 11 \mathrm{c}^{-}$cells from the respective tissues. In the tonsil, intermediate levels of CD5, CD7, CD25, CD127, HLA-DR, and $\mathrm{TdT}$ on $\mathrm{CD} 34^{+} \mathrm{CD} 38^{\text {bright }} \mathrm{Lin}^{-}$exemplify this.

The $\mathrm{CD} 34^{+} \mathrm{CD} 1 \mathrm{a}^{+} \mathrm{CD} 11 \mathrm{c}^{-}$populations in the thymus and tonsil are remarkably similar. Both expressed the early $\mathrm{T}$ cell markers CD2, CD5, CD7, CD10, and icCD3e. Furthermore, both demonstrated moderate levels of CD127 and intracellular TdT, an enzyme necessary for TCR gene rearrangement. Portions of the $\mathrm{CD} 34^{+} \mathrm{CD} 1 \mathrm{a}^{+} \mathrm{CD} 11 \mathrm{c}^{-}$subset in both the tonsil and thymus expressed $\mathrm{CD} 4$, suggesting that some $\mathrm{CD} 34^{+} \mathrm{CD} 1 \mathrm{a}^{+}$cells may be progressing to the immature single-positive stage, characteristic of normal thymocyte development (1). Like their thymic counterparts, tonsillar $\mathrm{CD} 34^{+} \mathrm{CD} 1 \mathrm{a}^{+} \mathrm{CD} 11 \mathrm{c}^{-}$cells did not express the GMCSF receptor (CD116) or HLA-DR, consistent with the hypothesis that they are not DCs (Figure 2).

$C D 4^{+} C D 8^{+} C D 1 a^{+} D P$ pre-T cells reside within the human tonsil. If the human tonsil supports complete $\mathrm{T}$ cell development, it should contain DP pre-T cells. However, Nascimbeni et al. have identified peripheral blood $\mathrm{CD}^{+} \mathrm{DP} \mathrm{T}$ cells that have a mature memory function (20), indicating that CD4 and CD8 alone are not enough to distinguish DP lymphocytes as pre-T cells. CD34depleted tonsillar or thymic cells and total mononuclear peripheral blood cells were analyzed for expression of CD4, CD8, CD3, and $\mathrm{CD} 1 \mathrm{a}$. Indeed, a population of $\mathrm{CD} 4^{+} \mathrm{CD} 8^{+}$cells resides within the human tonsil, and it was divided into $\mathrm{CD} 1 \mathrm{a}^{+}$and $\mathrm{CD} 1 \mathrm{a}^{-}$cells. The tonsillar CD1 $\mathrm{a}^{-}$DP cells uniformly expressed CD3, whereas the CD1 $\mathrm{a}^{+} \mathrm{DP}$ cells variably expressed CD3, suggesting they contain CD3- $T$ cell precursors (Figure $3 \mathrm{~A}$ ). Furthermore, thymic DP cells expressed CD1a with similar $\mathrm{CD}^{+}$expression as seen on the tonsillar $\mathrm{CD} 1 \mathrm{a}^{+}$subset (Figure $\left.3 \mathrm{~A}\right)$. Conversely, blood DP cells were $\mathrm{CD} 1 \mathrm{a}^{-} \mathrm{CD}^{+}$(Figure $3 \mathrm{~A}$ ), consistent with the findings of Nascimbeni et al., who found that DP memory T cells lack CD1a (20). These findings suggest that expression of CD1a can distinguish among distinct subsets of DP lymphocytes. Furthermore, its expression on a fraction of $\mathrm{CD}^{+} \mathrm{CD}^{+} \mathrm{CD}^{+/-}$tonsillar cells, similar to that in the thymus, supports the hypothesis that pre-T cells reside within the tonsil.
In the thymus, CD1a is expressed throughout $\mathrm{T}$ cell development until its loss on naive $\mathrm{CD}^{+} \mathrm{T}$ cells (1). To investigate the relationship between $\mathrm{CD} 34^{+} \mathrm{CD} 1 \mathrm{a}^{+} \mathrm{CD} 11 \mathrm{c}^{-}$tonsillar cells and potential downstream $\mathrm{T}$ cell intermediates, CD19- tonsillar cells were enriched for CD1a-expressing cells. Like the CD $34^{+} \mathrm{CD} 1 \mathrm{a}^{+}$subset described in Figure 1 , the CD34-CD $1 \mathrm{a}^{+}$ fraction of the human tonsil can be divided into 2 distinct populations based on its expression of the DC marker CD11c (Figure 3B). CD34-CD 11 $\mathrm{c}^{-} \mathrm{CD} 1 \mathrm{a}^{+}$tonsillar cells displayed low forward and side scatter properties, suggesting they are small, agranular lymphocytes, whereas the $\mathrm{CD} 11 \mathrm{c}^{+} \mathrm{CD} 1 \mathrm{a}^{+}$subset displayed higher forward and side scatter (Figure $3 \mathrm{~B}$ ). In contrast to those in the tonsil, CD34-CD $1 \mathrm{a}^{+}$cells in the human thymus were largely $\mathrm{CD} 11 \mathrm{c}^{-}$and displayed low forward and side scatter (Figure 3B). These data suggest that CD11c expression in the human tonsil is useful for distinguishing large CD $1 \mathrm{a}^{+} \mathrm{DCs}$ from what we believe to be a novel population of small CD $11 \mathrm{c}^{-}$ CD1 $\mathrm{a}^{+}$lymphocytes.

Tonsillar cells were next enriched for cells expressing CD34, CD1a, or a combination of both and analyzed for the expression of CD11c, CD34, CD1a, and CD3. It appears that both CD1a thymic and tonsillar cells lose CD34 expression as they increase CD1a surface density (Figure 3C, left). Furthermore, when the enriched cells were gated on total CD34-CD $11 \mathrm{c}^{-}$events, a similar progres-

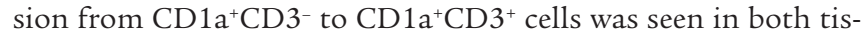
sues (Figure 3C, right). As CD1a expression is seen on thymocytes, spanning from $\mathrm{CD} 34^{+}$precursors all the way to $\mathrm{CD}^{+}$near-mature T cells (1), these data suggest that a similar pattern describes putative $T$ cell developmental intermediates of the tonsil.

Tonsillar $\mathrm{CD} 34^{-} \mathrm{CD} 1 \mathrm{a}^{+} \mathrm{CD} 11 c^{-}$cells express $T$ cell antigens in patterns similar to those of human thymocytes. The relationship of CD34, $\mathrm{CD} 1 \mathrm{a}$, and $\mathrm{CD} 3$ as well as the identification of $\mathrm{CD} 1 \mathrm{a}^{+} \mathrm{CD} 4^{+} \mathrm{CD} 8^{+}$ DP cells suggest that the human tonsil can support $\mathrm{T}$ cell development. After gating on CD34-CD11 $\mathrm{c}^{-}$tonsil or thymic cells,

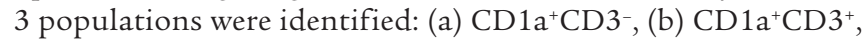
and (c) $\mathrm{CD}_{1} \mathrm{a}^{-} \mathrm{CD}^{+}$cells (Supplemental Figure 1A; supplemental material available online with this article; doi:10.1172/ JCI46125DS1). Expression of thymocyte-associated antigens was analyzed on these 3 populations from the tonsil and thymus (Figure 4). In both tissues, the expression of early thymocyte markers, such as CD10 and intracellular TdT, decreases as cells progressed from $\mathrm{CD} 1 \mathrm{a}^{+} \mathrm{CD}^{-}$to $\mathrm{CD} 1 \mathrm{a}^{+} \mathrm{CD}^{+}$, whereas the $\mathrm{CD} 1 \mathrm{a}^{-} \mathrm{CD}^{+}$cells did not express these markers in either tissue. In both the tonsil and thymus, CD5 and CD7 increased as cells progress through the 3 identified populations. $\mathrm{CD} 1 \mathrm{a}^{+} \mathrm{CD} 3^{-}$and $\mathrm{CD} 1 \mathrm{a}^{+} \mathrm{CD}^{+}$cells from both tissues expressed CD4, and many coexpressed CD8, although donor variation in CD8 expression was observed (data not shown). Finally, cells from all 3 subsets expressed icCD $3 \varepsilon$, and surface expression of TCR $\gamma \delta$ and TCR $\alpha \beta$ began at the $\mathrm{CD} 1 \mathrm{a}^{+} \mathrm{CD}^{+}$stage in both the thymus and tonsil. Total tonsillar and thymic CD34-CD $11 \mathrm{c}^{-} \mathrm{CD} 1 \mathrm{a}^{+}$cells did not express the lineage markers CD56, CD117, CD94, CD16, CD19, CD14, BDCA-2, or CD116, but a small subset expressed CD161 (Supplemental Figure 1, B and C). Thus, total tonsillar $\mathrm{CD} 1 \mathrm{a}^{+} \mathrm{CD} 11 \mathrm{c}^{-}$cells phenotypically resemble CD $1 \mathrm{a}^{+}$cells in the human thymus. Furthermore, early thymocyte antigen loss and the acquisition of mature $T$ cell-associated antigens suggest that $\mathrm{CD}^{3} 4^{-} \mathrm{CD} 11 \mathrm{c}^{-}$tonsillar precursors progress from $\mathrm{CD} \mathrm{a}^{+} \mathrm{CD} 3^{-}$cells, which acquire $\mathrm{CD} 3$ and then lose CD1a, to become mature $\mathrm{CD} 1 \mathrm{a}^{-} \mathrm{CD} 3^{+} \mathrm{T}$ cells. 
A

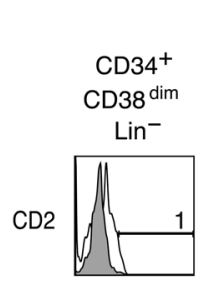

${ }_{\mathrm{icCD}} \varepsilon$
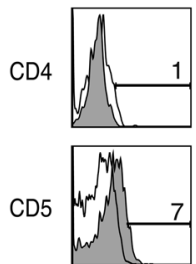

CD7

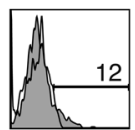

CD8

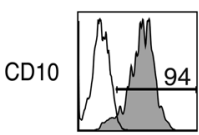

CD25 29

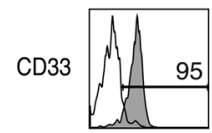

CD45RA $/ 96$

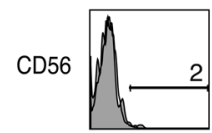

CD116 0
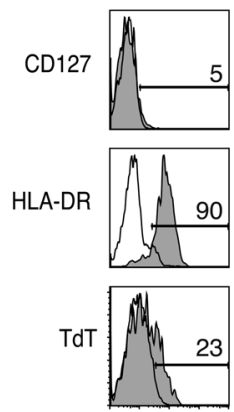

Tonsil
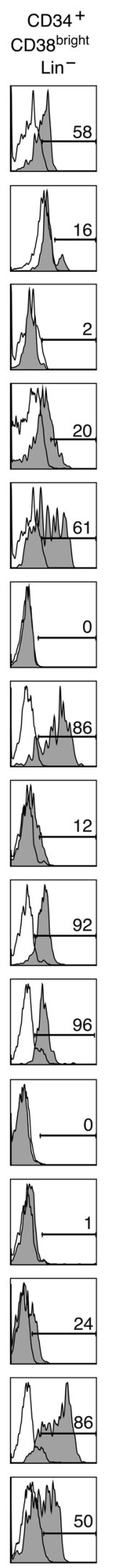

$\mathrm{CD} 34^{+}$

${\mathrm{CD} 1 \mathrm{a}^{+}}^{+}$

$\mathrm{CD}^{11 \mathrm{C}^{-}}$
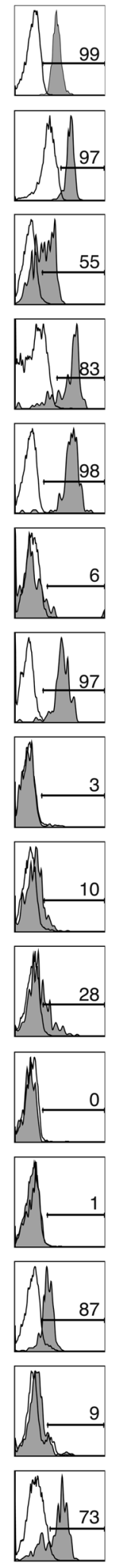

B
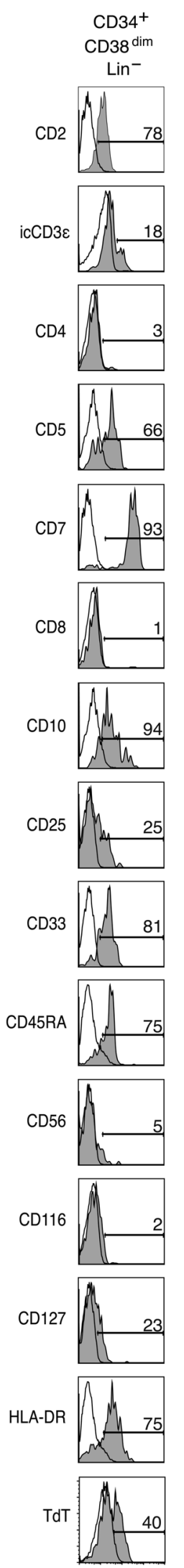

Thymus
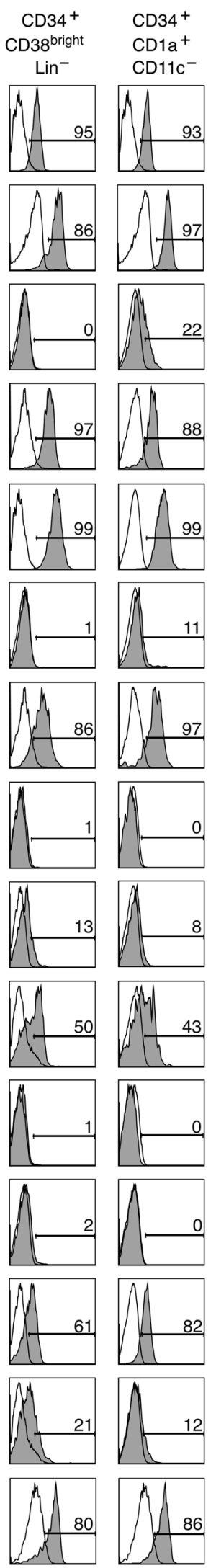

Figure 2

Phenotypic comparison of CD34+CD38dimLin-, CD34 ${ }^{+}$CD38 bright Lin ${ }^{-}$, and $\mathrm{CD} 34{ }^{+} \mathrm{CD} 1 \mathrm{a}^{+} \mathrm{CD} 11 \mathrm{c}^{-}$ cells in human tonsil and thymus. (A) Tonsillar cells were magnetically depleted of CD3- and CD19-expressing cells and were then enriched for $\mathrm{CD} 34^{+}$cells. Enriched cells are gated on

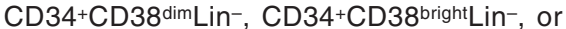
CD34 ${ }^{+} \mathrm{CD} 1 \mathrm{a}^{+} \mathrm{CD} 11 \mathrm{c}^{-}$events. (B) Thymic cells were magnetically enriched for $\mathrm{CD} 34^{+}$cells and then gated on the same 3 populations as in $\mathbf{A}$. Gray shading indicates staining with the indicated antibody, whereas no shading indicates staining with an isotype-matched control antibody. The number above each gate indicates the percentage of events falling within that gate. Data in each histogram is from a representative donor, where $n \geq 3$ for tonsil and $n \geq 2$ for thymic data.

Expression of $T$ cell development-associated genes in putative tonsillar $T$ cell precursors. Specific gene expression patterns in the human thymus can be used to track the development of $\mathrm{T}$ cell precursors as they progress from multipotent cells toward mature T cells. For example, RAG1 and PTCRA, both of which are required for successful TCR rearrangement, are expressed early in $\mathrm{T}$ cell development and peak at the $\mathrm{CD} 34^{+} \mathrm{CD} 1 \mathrm{a}^{+}$and $\mathrm{DP}$ pre- $\mathrm{T}$ cell stages $(3,6)$. Similarly, expression of $B C L-X$ has been detected in both murine and human $\mathrm{CD}^{+} \mathrm{CD}^{+}$DP thymocytes, and the $B C L-X_{L}$ (also known as BCL2L1) isoform has been shown to be critical for providing necessary antiapoptosis signals in murine DP cells $(21,22)$. In contrast, THPOK is a transcription factor that is essential for development of mature $\mathrm{CD}^{+}$cells, and its expression in the thymus and periphery is largely restricted to $\mathrm{CD}^{+}$cells (23).

Thus, we used real-time RT-PCR to assess expression of these 4 genes within putative $\mathrm{T}$ cell precursor populations in the human tonsil. Six distinct populations were sorted from human tonsil and thymus, as shown in Figure 5A: (a) CD34+CD38 ${ }^{\text {dim }}$ Lin $^{-}$, (b) $\mathrm{CD}^{+} 4^{+} \mathrm{CD} 38^{\text {bright }} \mathrm{Lin}^{-}$, (c) $\mathrm{CD} 34^{+} \mathrm{CD}_{1 \mathrm{a}^{+} \mathrm{CD}}{ }^{-}$, (d) CD34-CD1a ${ }^{+} \mathrm{CD}^{-}$, (e) $\mathrm{CD} 34^{-} \mathrm{CD}^{-} \mathrm{a}^{+} \mathrm{CD}^{+}$, and (f) $\mathrm{CD}^{-} 4^{-} \mathrm{CD} 1 \mathrm{a}^{-} \mathrm{CD} 3^{+}$cells. The complete gating strategy and representative sort purities are shown in Supplemental Figure 2, and the relative frequencies of each tonsillar subset are shown in Supplemental Table 1. In duplicate experiments, the levels of RAG1 (Figure 5B), PTCRA (Figure $5 \mathrm{C}$ ), and BCL2L1 (Figure 5D) mRNA were highest in either population 3 or 4 of the tonsil. Expression of THPOK mRNA, on the other hand, was largely restricted 
A

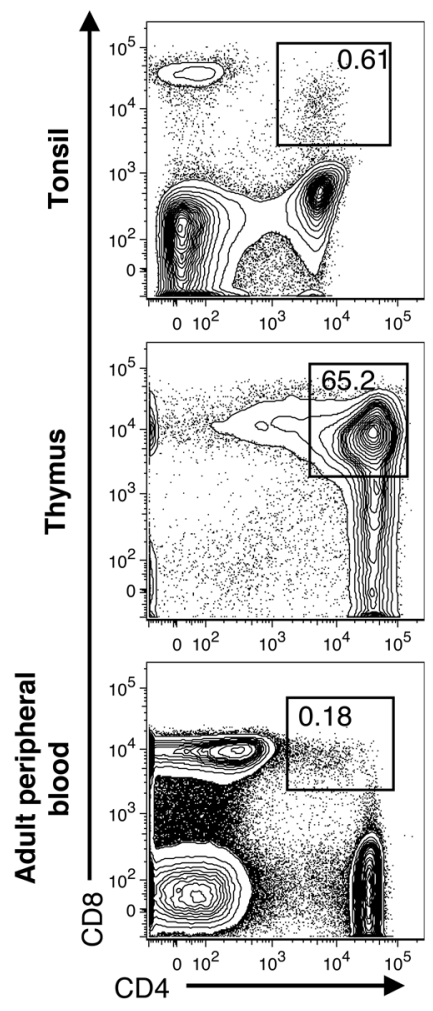

B
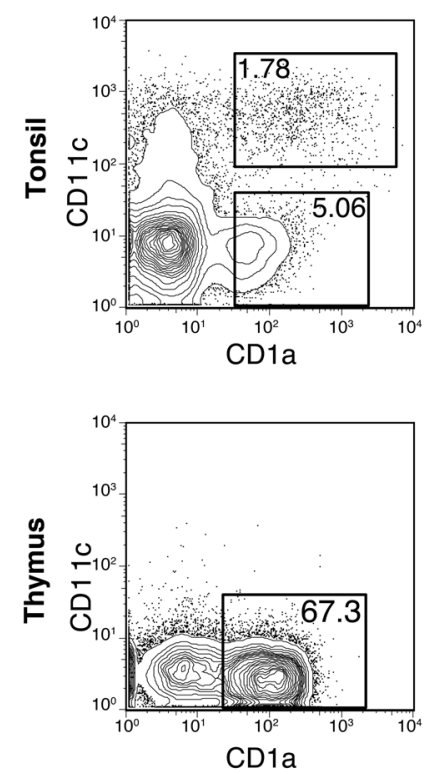
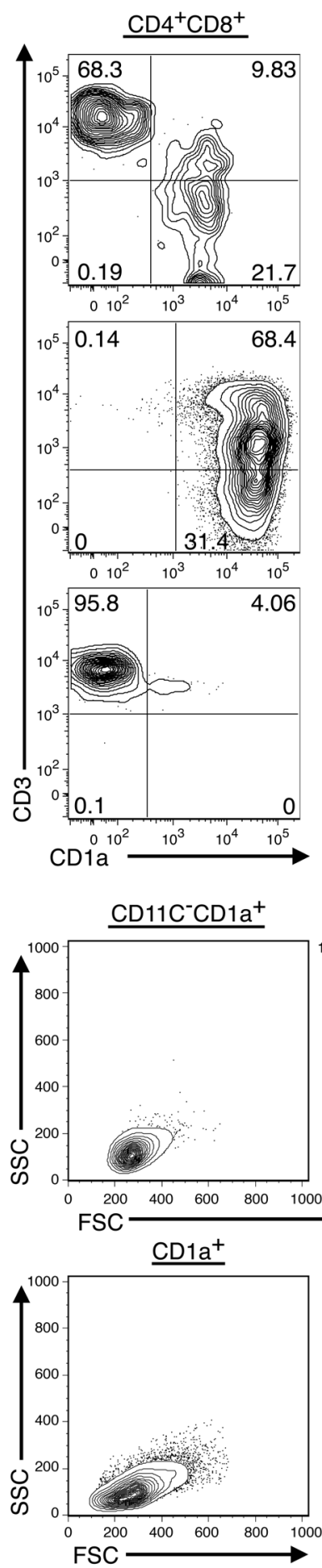

C

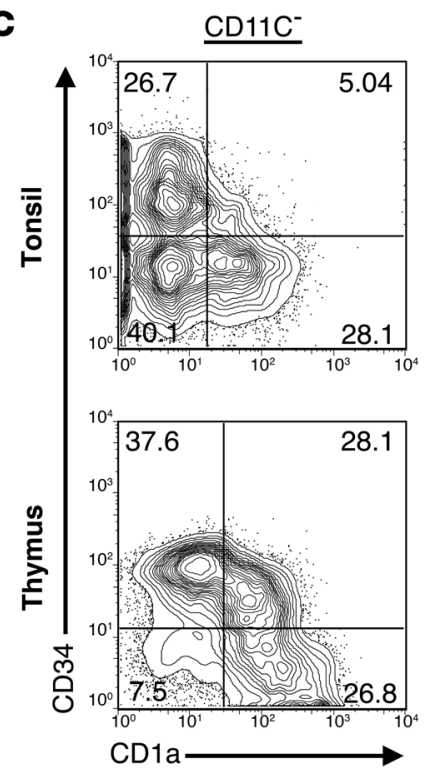

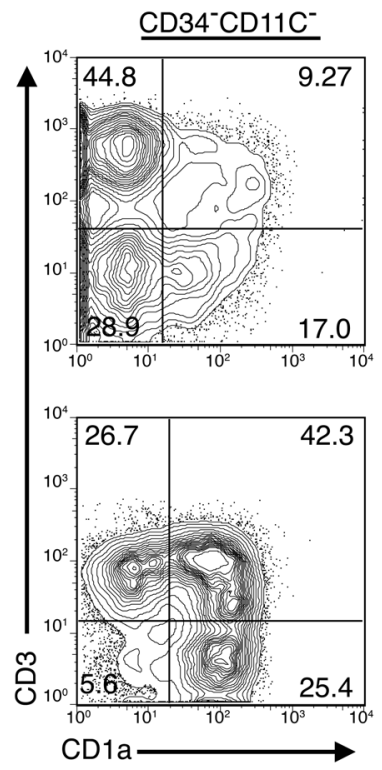

Figure 3

CD $4{ }^{+} \mathrm{CD} 8{ }^{+} \mathrm{CD} 1 \mathrm{a}^{+}$cells reside within the human tonsil. (A) CD34-depleted cells from the human tonsil and thymus and total peripheral blood mononuclear cells were analyzed for expression of DP cells (left). DP events were then analyzed for expression of CD1a and CD3 (right). (B) CD19depleted tonsillar cells were magnetically enriched for CD1a-expressing cells. CD34CD1 ${ }^{+}$CD11 $c^{-}$and CD34-CD1 ${ }^{+}+{ }^{-C D 11 c^{+}}$ tonsillar cells were analyzed for their forward scatter (FSC) and side scatter (SSC) properties. CD34- thymic cells were analyzed for expression of CD1a and CD11c, and $\mathrm{CD}_{1 \mathrm{a}^{+}}$thymic cells were analyzed for forward and side scatter properties. (C) CD19-depleted tonsillar cells were simultaneously enriched for both CD34- and CD1a-expressing cells. Enriched cells were gated on $\mathrm{CD}_{11 \mathrm{c}^{-}}$(left) or CD34CD11 $\mathrm{c}^{-}$(right) events and analyzed for expression of CD34 and CD1a (left) and CD3 and CD1a (right). Thymic CD34+ and CD34- cells were similarly analyzed after CD34 enrichment. Data are representative of 1 out of at least 3 independent donors. Numbers within each gate represent the percentage of events falling within that gate for the representative donor shown.

to the $\mathrm{CD}^{+}$populations 5 and 6 (Figure 5E). These patterns of gene expression were found to be similar to the patterns noted in the comparable thymic populations (Figure 5, B-E).

In situ localization of tonsillar $\mathrm{CD}^{2} 4^{+} \mathrm{Td} \mathrm{T}^{+}$and $\mathrm{CD} 1 \mathrm{a}^{+} \mathrm{Td} \mathrm{T}^{+}$cells. $\mathrm{TdT}^{+}$ cells have been identified in the human tonsil near the fibrous scaffold (8-11). However, they have yet to be characterized with regard to origin, hematopoietic lineage, or function. Our identification of $\mathrm{CD} 1 \mathrm{a}^{+} \mathrm{CD} 11 \mathrm{c}^{-} \mathrm{TdT}^{+}$cells in the tonsil suggests that the previously identified $\mathrm{TdT}^{+}$cells may be extrathymic $\mathrm{T}$ cell precursors. Paraffin-embedded pediatric tonsils were analyzed by immunohistochemistry for the presence of TdT, CD34, CD1a, CD11c, and Rag1. We confirmed that $\mathrm{TdT}^{+}$cells are largely restricted to the extrafollicular regions near the fibrous scaffold of the tonsil (Figure 6A). Further, these cells did not express CD11c (data not shown) but did variably coexpress CD34, CD1a (Figure 6B), and/or nuclear Rag1 (Supplemental Figure 3). Furthermore, $\mathrm{CD} 34^{+} \mathrm{CD} 1 \mathrm{a}^{+}$cells were easily identified in the same region of the tonsil fibrous scaffold (Figure $6 \mathrm{~B}$ ). $\mathrm{TdT}^{+}$cells were 


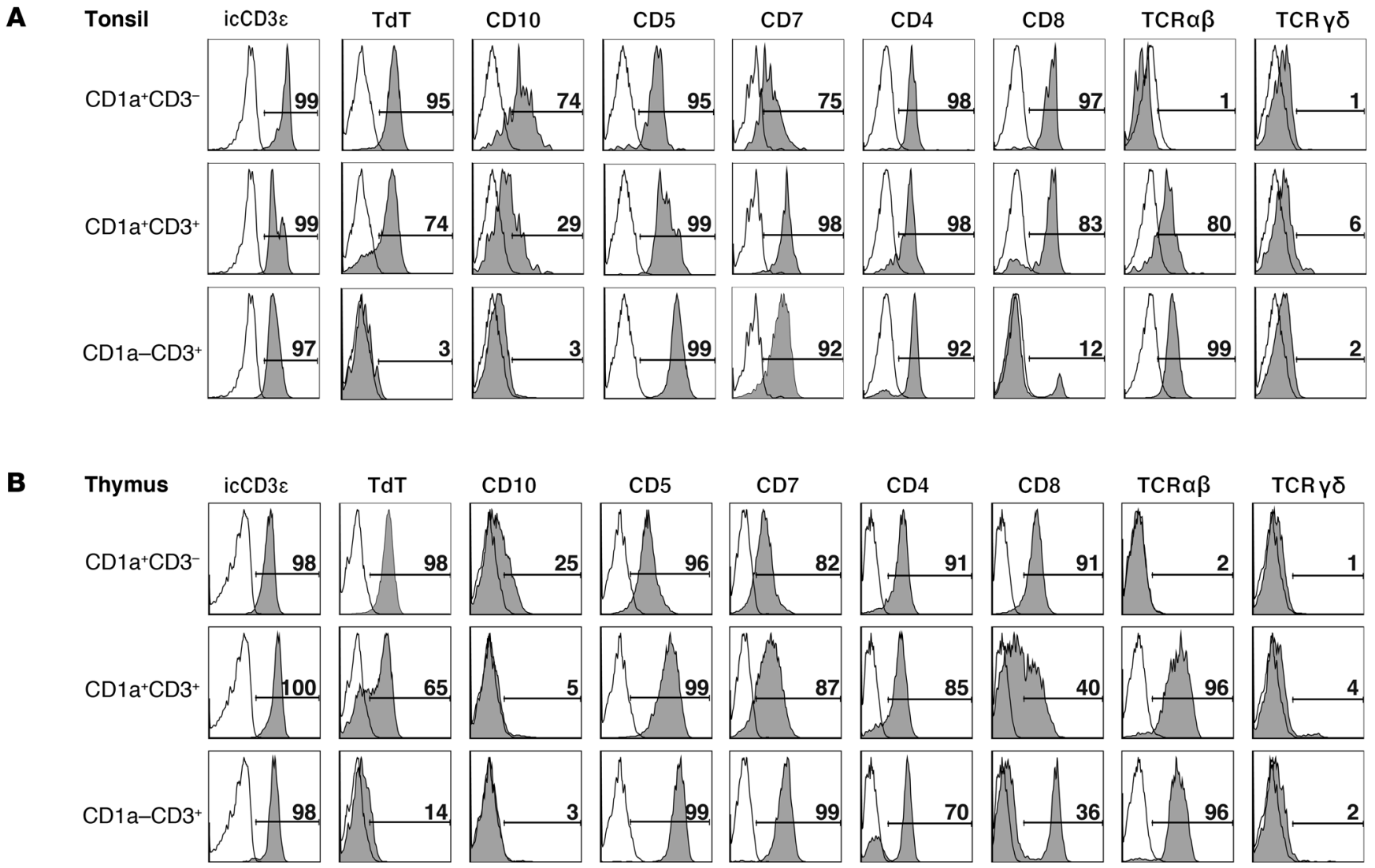

Figure 4

Putative $T$ cell precursors in the human tonsil acquire T-associated antigens in a fashion similar to that of those in the thymus. (A) CD1a-

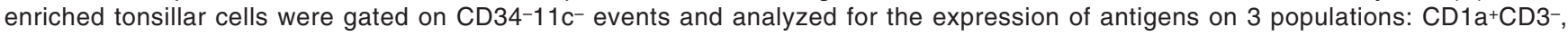
$\mathrm{CD}_{1} \mathrm{a}^{+} \mathrm{CD}^{+}$, and $\mathrm{CD} \mathrm{a}^{-} \mathrm{CD}^{-}$. (B) CD34-depleted thymic cells were gated on the same 3 populations and analyzed as in A. Gray shading indicates staining with the indicated antibody, whereas no shading indicates staining with an isotype-matched control antibody. The number listed above each gate indicates the percentage of events falling within that gate. Data in each histogram are from a representative donor, where $n \geq 3$ for tonsil and $n \geq 2$ for thymic data.

identified in both pediatric and adult tonsil. Analyses performed in adult reactive lymph nodes revealed that rare $\mathrm{TdT}^{+}$cells could be identified, but no coexpression of CD1a or CD34 was observed (data not shown). To further examine the microenvironment of tonsillar $\mathrm{TdT}^{+}$cells, we used immunohistochemistry to analyze the expression of the notch ligands delta-like 1 (DL1) and deltalike 4 (DL4) within the tonsil fibrous regions, as notch ligands are essential for complete $T$ cell development (24-27). Both proteins were easily identified (Figure 6C), further supporting the hypothesis that the tonsil may contribute to extrathymic $\mathrm{T}$ cell development. Taken together, these data suggest that the $\mathrm{TdT}^{+}$ cells previously identified in the tonsil belong to a program of extrathymic $T$ cell differentiation and localize to a specific microenvironment near the tonsillar fibrous scaffold.

Ex vivo T cell differentiation potential of putative extratbymic T cell precursors. To determine whether the putative extrathymic $T$ cell precursors have the capacity to differentiate into mature T cells, the 6 populations were sorted from the tonsil and thymus, as shown in Figure 5A and Supplemental Figure 2, and were cultured on the OP9-DL1 cell line with flt 3 ligand (FL) and IL-7. After 26 days, the cells were harvested and analyzed by flow cytometry. To exclude the $\mathrm{GFP}^{+} \mathrm{OP9}$-DL1 cells, harvested cells were gated on $\mathrm{GFP}^{-} \mathrm{CD} 45^{+}$ events. Populations 1-3 from the tonsil and thymus expanded 93270 fold, whereas populations 4-6 only expanded 1-6 fold (Supplemental Table 2). All 6 populations from the tonsil and thymus gave rise to $\mathrm{CD}^{+}$cells. In the tonsil and thymus, the percentage of GFP-CD $45^{+}$cells that coexpress CD4 and CD8 increased as the cells progressed from population 1 to population 4 (Figure 7). Furthermore, in both the tonsil and thymus, the percentage of GFP-CD45 cells that express CD3 increased as one progressed from population 1 to population 6 , as did the percentage of $\mathrm{CD}^{+}$cells that coexpress a TCR (Figure 7 and Supplemental Figure 4, A and B). When we compared the relative ability of each tonsillar population to generate mature $T$ cells with that of the same populations in the thymus, we found that population 2 and 3 cells from the thymus generated a significantly higher proportion of $\mathrm{CD}^{+}$cells than did populations 2 and 3 from the human tonsil (population 2, 51.9\% \pm $7.0 \%$ from the thymus vs. $4.1 \% \pm 1.12 \%$ from the tonsil, $P<0.0001$; population $3,57.23 \% \pm 4.8 \%$ from the thymus vs. $32.36 \% \pm 8.1 \%$ from the tonsil, $P=0.0044$; Supplemental Figure 4A). Similarly, we found that thymic populations 2 and 3 generated significantly more $\mathrm{CD}^{+}$cells that coexpressed a TCR (either TCR $\alpha \beta$ or TCR $\gamma \delta$ ) than did the same populations in the tonsil (population 2, 39.3\% \pm $8.5 \%$ from the thymus vs. $1.41 \% \pm 0.6 \%$ from the tonsil, $P<0.0001$; 
A
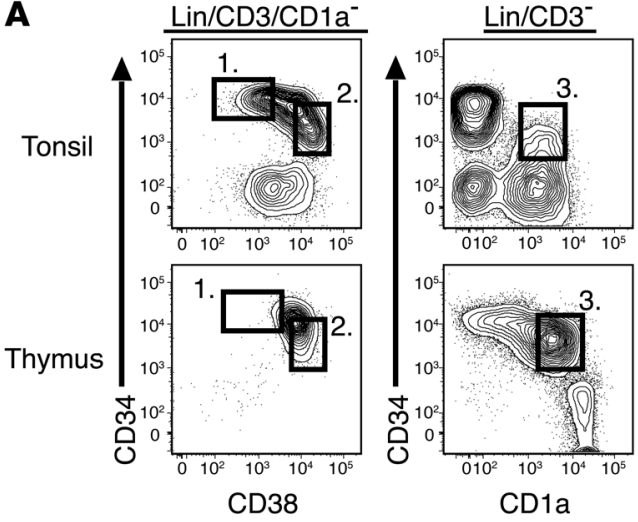

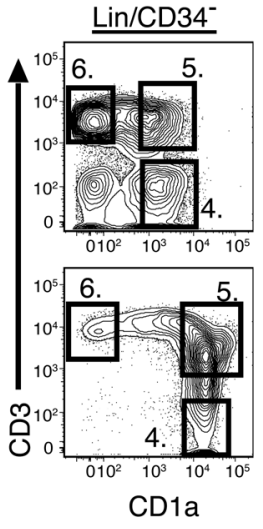

1. $\mathrm{CD} 34^{+} \mathrm{CD} 38^{\mathrm{dim}} \mathrm{CD} 3 / \mathrm{CD} 1 \mathrm{a} / \mathrm{Lin}^{-}$ 2. $\mathrm{CD} 34^{+} \mathrm{CD} 38^{\text {bright }} \mathrm{CD} 3 / \mathrm{CD} 1 \mathrm{a} / \mathrm{Lin}^{-}$

3. $\mathrm{CD}^{+} 4^{+} \mathrm{CD} 1 \mathrm{a}^{+} \mathrm{CD}^{-} \mathrm{Lin}^{-}$

4. $\mathrm{CD}^{-} 4^{-} \mathrm{CD} 1 \mathrm{a}^{+} \mathrm{CD}^{-} \mathrm{Lin}^{-}$

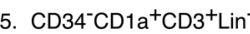

6. $\mathrm{CD} 34^{-} \mathrm{CD} 1 \mathrm{a}^{-} \mathrm{CD} 3^{+} \mathrm{Lin}^{-}$
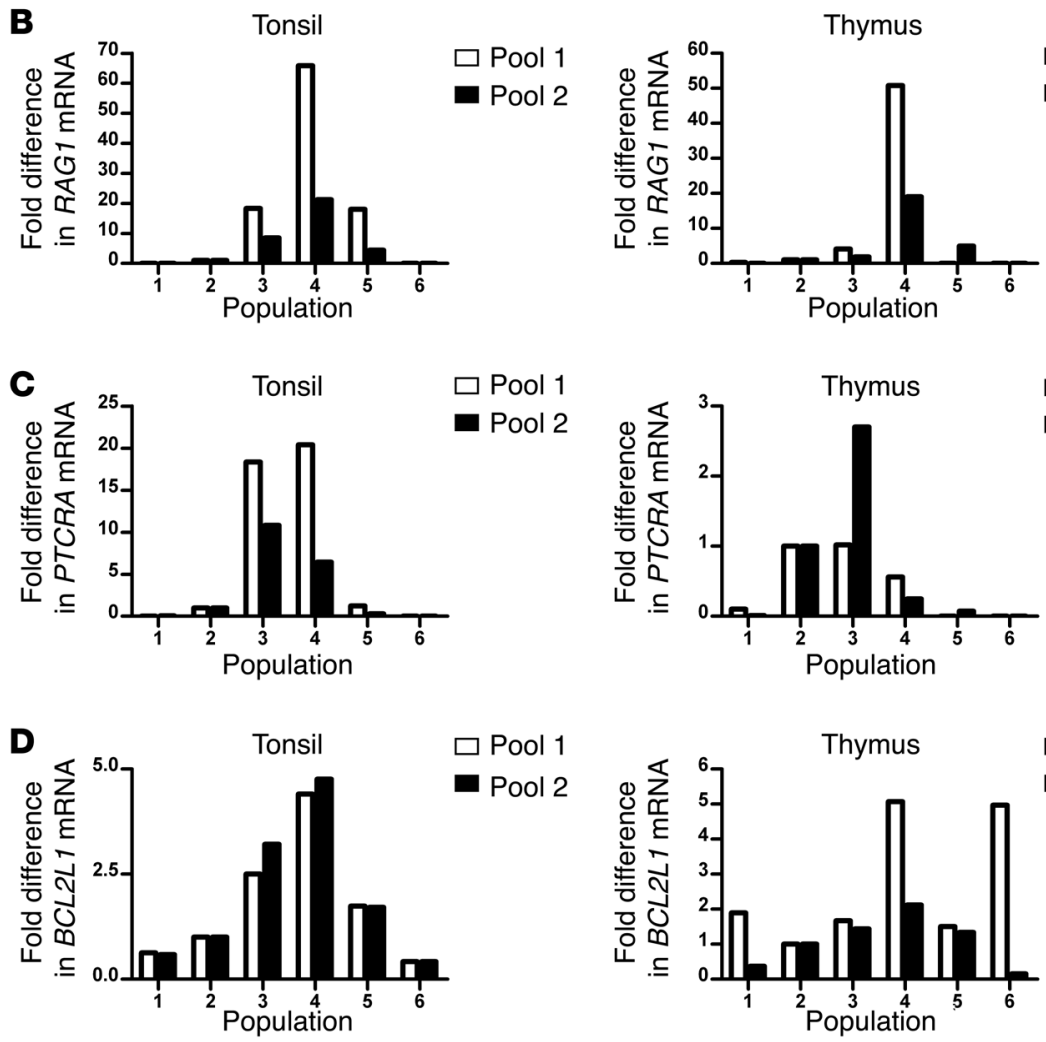

$\square$ Pool 1

Pool 2

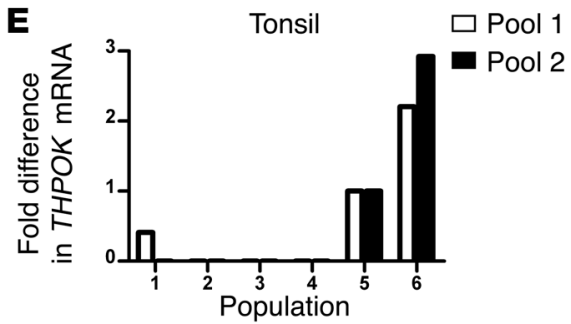

Figure 5

Quantification of gene expression in tonsillar precursor cells by realtime RT-PCR. (A) Tonsillar cells were depleted of CD19+ cells, enriched for $\mathrm{CD}_{3} 4^{+}$and $\mathrm{CD} 1 \mathrm{a}^{+}$ cells, and gated on the 6 populations shown. (B-E) Expression of the genes RAG1, PTCRA, $B C L 2 L 1$, and THPOK in 6 populations of human tonsillar and thymic cells. Cells were sorted from 8 tonsil donors, and 2 pools were generated for each population consisting of cells from 4 of the 8 donors (see Methods). Cells were sorted from 2 thymic donors. (B-D) For analysis of RAG1, PTCRA, and BCL2L1, expression is displayed relative to that of population 2, which was arbitrarily set at 1 . (E) For THPOK, expression is displayed relative to that of population 5 for the tonsil and population 6 for the thymus, each of which was arbitrarily set at 1 . population $3,44.1 \% \pm 7.2 \%$ from the thymus vs. $20.3 \% \pm 5.7 \%$ from the tonsil, $P=0.0041$; Supplemental Figure 4B). No statistical difference was observed in the percentage of $\mathrm{GFP}^{-} \mathrm{CD} 45^{+}$cells that were $\mathrm{CD}^{+}$or $\mathrm{CD}^{+} \mathrm{TCR}^{+}$when we compared tonsillar populations $1,4,5$, or 6 with those same populations in the human thymus. Several controls were performed to rule out contamination from mature tonsillar $\mathrm{T}$ cells as being responsible for the observed out- growth of $\mathrm{CD}^{+}$cells from cultures of populations $1-4$. For example, CD $19^{+}$tonsillar cells were similarly sorted and cultured on the OP9-DL1 cell line. After 26 days, no $\mathrm{CD}^{+}$cells were generated from the $\mathrm{CD} 19^{+}$tonsillar cells. Thus, these data demonstrate that

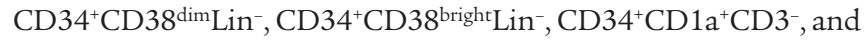
CD34-CD1 $\mathrm{a}^{+} \mathrm{CD} 3^{-}$tonsillar cells (populations 1-4) contain differentiation potential for $\mathrm{T}$ cell development ex vivo. 
A

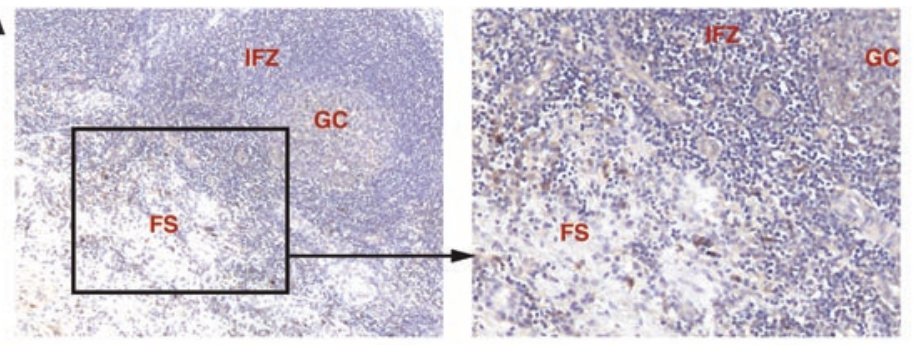

B

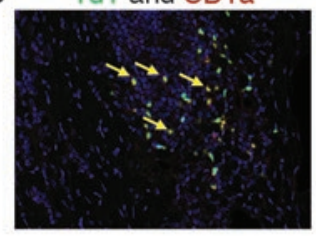

C

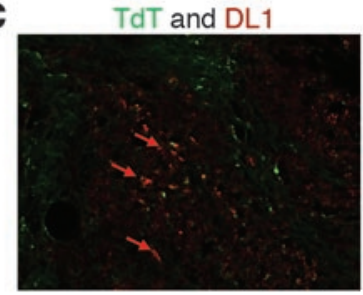

TdT and CD34
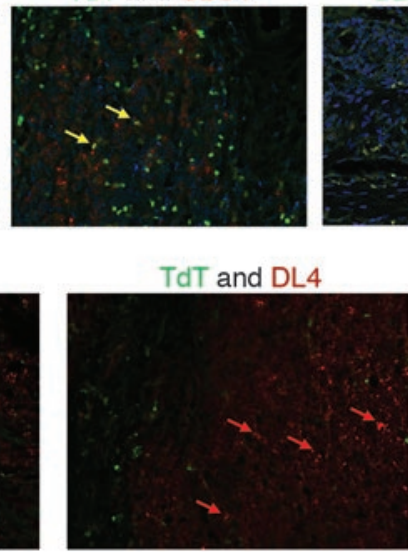

\section{Figure 6}

CD1 ${ }^{+}{ }^{+} \mathrm{CT}^{+}$cells reside near the fibrous scaffold of the human tonsil. (A) Immunohistochemical staining of paraffinembedded tonsillar sections shows TdT+ cells (dark brown) localized to the fibrous scaffold region. The image on the left (original magnification, $\times 50$ ) is of a representative section, including a germinal center (GC), the surrounding interfollicular zone (IFZ), and an adjacent fibrous scaffold region (FS). The image on the right is of the same tonsil section, but at an original magnification of $\times 100$. (B) Cells coexpressing TdT, CD1a, and CD34 are found within the scaffold region of the tonsil. TdT (green) and CD1a (red) coexpression is shown on the left, TdT (green) and CD34 (red) coexpression is shown in the middle, and CD34 (green) and CD1a (red) are shown on the right. Note the yellow cells in each section, which represent cells coexpressing both proteins of interest (yellow arrows). Blue staining indicates hematoxylin counterstain. (C) TdT (green), DL1 (red), and DL4 (red) proteins are expressed in the same geographical region of the human tonsil. Original magnification, $\times 400$ (B and C).
To gain further insight into the kinetics of $\mathrm{T}$ cell development from tonsillar precursor cells, we sorted populations 1-6 from the tonsil and cultured them on the OP9-DL1 cell line with exogenous FL and IL-7 for either 7 or 14 days. Whereas a few of the $\mathrm{GFP}^{-} \mathrm{CD}_{4} 5^{+}$progeny were $\mathrm{CD}^{+}$at days 7 or 14 , only a very small percentage of these $\mathrm{CD}^{+}$cells coexpressed a TCR (Supplemental Figure 4, C and D). This suggests that TCR expression is an event that occurs later in $\mathrm{T}$ cell development and confirms that the appearance of mature $\mathrm{T}$ cells at 26 days is not simply an artifact of contamination by tonsillar $\mathrm{CD}^{+} \mathrm{TCR}^{+}$cells. Furthermore, in 26-day cultures with FL and IL-7 on the OP9 stromal cell line, which lacks notch ligand expression, populations 1-4 from the tonsil failed to generate $\mathrm{CD}^{+} \mathrm{TCR}^{+} \mathrm{T}$ cells. Tonsillar populations 5 and 6 , on the other hand, maintained a population of $\mathrm{CD}^{+} \mathrm{TCR}^{+}$ cells in these conditions (data not shown).

Ex vivo NK cell differentiation potential of putative extrathymic $T$ cell precursors. Human NK cell development has been studied extensively in human tonsils and lymph nodes (12-14, 28-31). To examine whether extrathymic $T$ cell precursors could contribute to tonsillar NK cell development as well, the 6 populations identified in Figure 5A were cultured with FL, c-kit ligand (KL), IL-3, IL-7, and IL-15 on the OP9 stromal cell line. Whereas cultures of populations 5 and 6 from both tissues remained exclusively $\mathrm{CD}^{+}$(Figure $8 \mathrm{~A}$ ), populations $1-3$ from both the tonsil and thymus gave rise to $\mathrm{CD}_{56} 6^{+} \mathrm{CD}^{-} \mathrm{NK}$ cells. Population 4 cells from the tonsil gave rise to $\mathrm{CD} 56^{+} \mathrm{CD} 3^{-}$cells in 3 out of 3 experiments, whereas thymic population 4 cells gave rise to $\mathrm{CD} 56^{+} \mathrm{CD} 3^{-}$cells in 1 out of 5 experiments, although no population 4 cells survived in 3 out of these 5 thymic experiments. The resulting $\mathrm{CD}^{2} 6^{+}$cells derived from tonsil and thymus expressed CD161 and low levels of NKp46 (Figure 8, B and $\mathrm{C}$ ), along with variable expression of CD5, the latter of which increased from less than $10 \%$ in tonsillar populations 1 and 2 to more than $50 \%$ in populations 3 and 4 .
To further investigate the T and NK cell differentiation capabilities of putative extrathymic $T$ cell precursors in the tonsil, single cells were sorted from tonsillar populations 1-4 into wells containing OP9-DL1 cells and the cytokines FL, IL-7, and IL-15. The individual cells were cultured in this system for 14 days. After culture, each well was harvested and examined for the presence of $\mathrm{CD}^{+} \mathrm{CD}^{-} \mathrm{T}$ cell precursors, $\mathrm{CD}^{+} \mathrm{T}$ cells, or $\mathrm{CD}^{-} 6^{+} \mathrm{CD}^{-} \mathrm{NK}$ cells (Supplemental Table 3). Between 16\% and 67\% of the wells plated sustained $\mathrm{CD}_{4} 5^{+}$cells at the time of harvest. This assay demonstrates that all 4 populations have the potential to differentiate into $\mathrm{CD}^{+} \mathrm{CD}^{-} \mathrm{T}$ cell precursors and $\mathrm{CD} 56^{+} \mathrm{CD}^{-} \mathrm{NK}$ cells and that there was an increasing tendency for a single cell to generate $\mathrm{CD}^{+}$cells as one progressed from population 1 through population 4. Occasionally, single cells from populations 2 and 3 gave rise to wells containing both $\mathrm{CD}^{+} \mathrm{T}$ cells and $\mathrm{CD} 56^{+} \mathrm{CD}^{-} \mathrm{NK}$ cells.

\section{Discussion}

We have identified 5 subsets of lymphocytes which we believe to be novel within the human tonsil: (a) CD $34^{+} \mathrm{CD} 38^{\mathrm{dim}} \mathrm{Lin}^{-}$, (b) $\mathrm{CD} 34^{+} \mathrm{CD} 38^{\text {bright }} \mathrm{Lin}^{-}$, (c) $\mathrm{CD} 34^{+} \mathrm{CD} 1 \mathrm{a}^{+} \mathrm{CD} 11 \mathrm{c}^{-}$, (d) $\mathrm{CD} 34^{-}$ CD $1 \mathrm{a}^{+} \mathrm{CD} 3{ }^{-} \mathrm{CD} 11 \mathrm{c}^{-}$, and (e) CD $34^{-} \mathrm{CD} 1 \mathrm{a}^{+} \mathrm{CD} 3^{+} \mathrm{CD} 11 \mathrm{c}^{-}$cells. We have provided phenotypic, gene expression, and functional evidence that these subsets represent intermediates in a program of extrathymic T cell development. Tonsil CD34 ${ }^{+} \mathrm{CD} 38^{\mathrm{dim} \mathrm{Lin}^{-}}$and $\mathrm{CD} 34^{+} \mathrm{CD} 38^{\text {bright }} \mathrm{Lin}^{-}$cells share many phenotypic properties of the same cells identified in the thymus and have differentiation potential to develop into T cells and NK cells. Remarkably, the $\mathrm{CD} 34^{+} \mathrm{CD} 1 \mathrm{a}^{+} \mathrm{CD} 11 \mathrm{C}^{-}$cells identified in the tonsil display a phenotype that is virtually identical to that of thymic CD $34^{+} \mathrm{CD} 1 \mathrm{a}^{+}$ $\mathrm{T}$ cell precursors and display consistent $\mathrm{T}$ cell developmental capabilities. Similarly, CD $34^{-} \mathrm{CD} 1 \mathrm{a}^{+} \mathrm{CD} 11 \mathrm{c}^{-}$cells of the tonsil highly resemble $\mathrm{CD} 34^{-} \mathrm{CD} 1 \mathrm{a}^{+}$cells of the thymus, in that they can be divided into 2 populations based on the expression of CD3, 


\section{A Starting population} 2 3 4 5
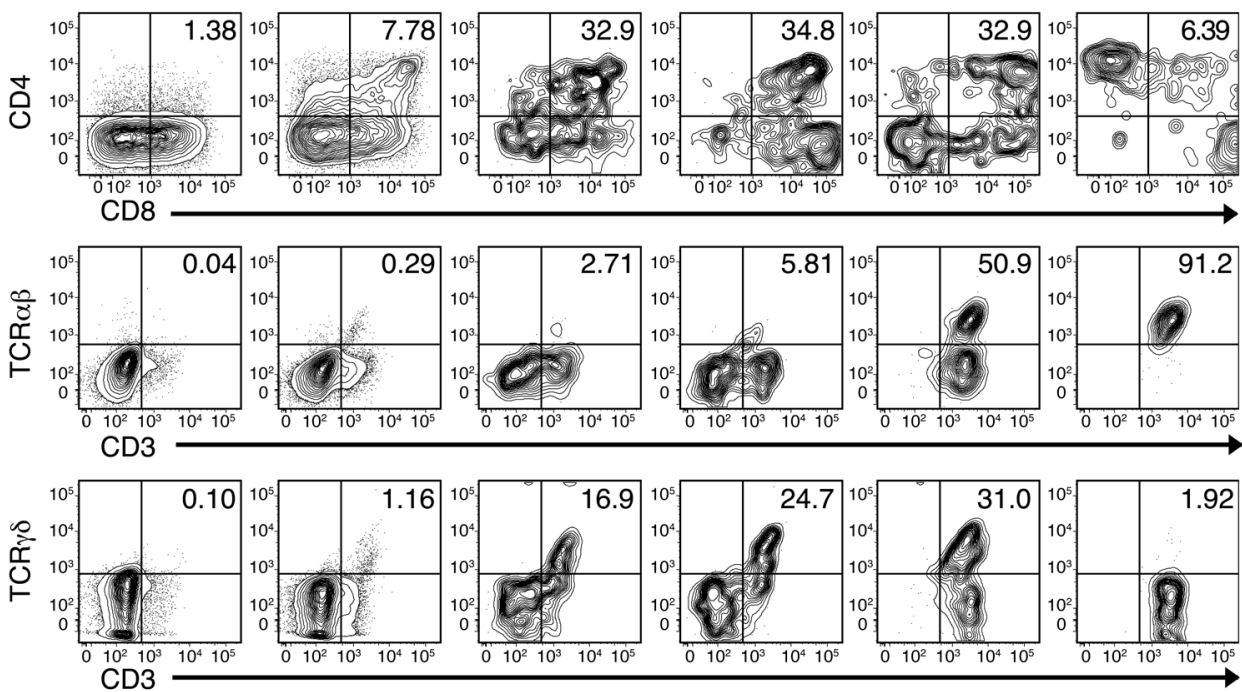

\section{B Starting population} 2 3
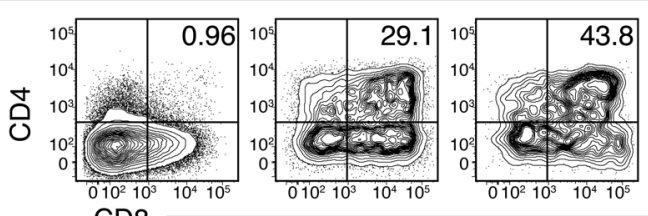

4

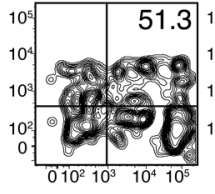
5 6
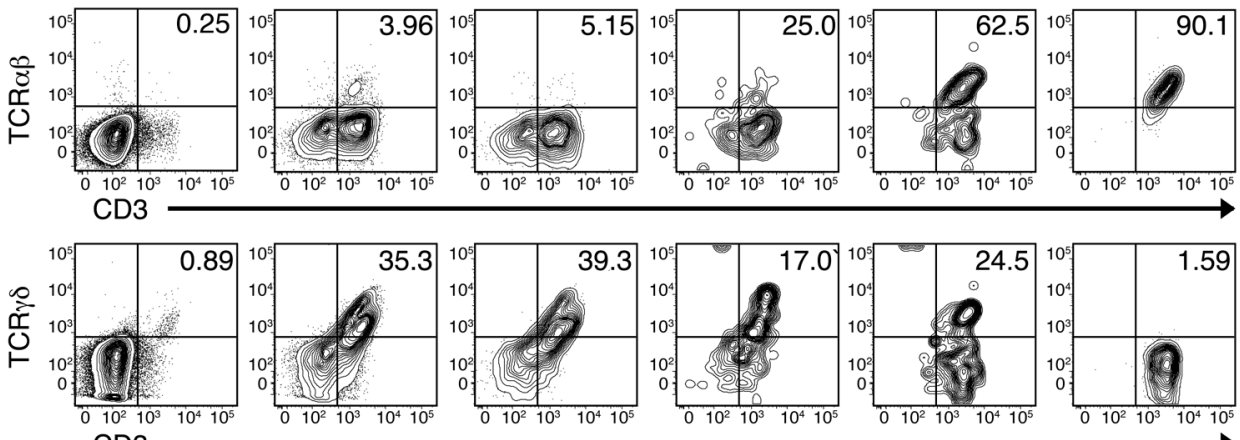

Figure 7

T cell differentiation potential of putative extrathymic T cell precursors in the human tonsil. (A and B) Cells were sorted from the human $(\mathbf{A})$ tonsil or (B) thymus, as indicated in Figure 5A. All 6 populations were cultured independently on OP9-DL1 cells with FL and IL-7 for 26 days. After harvest, cells were analyzed for the expression of CD3, CD4, CD8, TCR $\alpha \beta$, and TCR $\gamma \delta$. Data are gated on GFP-CD45+ events to exclude OP9DL1 stromal cells from analysis. Data shown are representative of experiments performed with 7 individual tonsils or 4 thymus donors. Numbers represent the mean percentages of GFP-CD45+ cells that stained positive for both antigens indicated on the dot plot.

they coexpress CD4 and CD8, and they retain T cell developmental potential. Furthermore, in addition to identifying $\mathrm{CD}_{1} \mathrm{a}^{+} \mathrm{TdT}^{+}$ extrathymic $\mathrm{T}$ cell precursors in human tonsil, we have localized the bulk of this population near fibrous scaffolding, suggesting that it resides in a distinct microenvironment. Finally, we have demonstrated that $\mathrm{CD} 34^{+/-} \mathrm{CD} 1 \mathrm{a}^{+} \mathrm{CD} 11 \mathrm{c}^{-}$cells from the thymus and tonsil are not committed to the $\mathrm{T}$ cell lineage but retain ex vivo differentiation potential to also develop into NK cells.

While previous reports have identified a role for murine intestinal lymphoid tissue in $\mathrm{T}$ cell development (32-35), the few studies investigating human extrathymic $T$ cell differentiation are difficult to interpret. It is known that uncommitted hematopoietic progenitors with $\mathrm{T}$ cell differentiation capabilities reside within the bone marrow $(6,36,37)$ and cord blood $(24$, $38)$. Furthermore, tonsillar $\mathrm{TdT}^{+}$cells of unclear etiology and pre-T $\alpha^{+}$cells within bone marrow and neonatal intestine have been identified (4, 7-9). However, a complete description of $T$ cell differentiation in an extrathymic human tissue has not been provided. Our work suggests that $\mathrm{T}$ cell development occurs in the human tonsil, and future studies should address what proportion of the total $\mathrm{CD}^{+}$tonsillar pool is derived within the tonsil compared with that from the thymus. 
A Starting

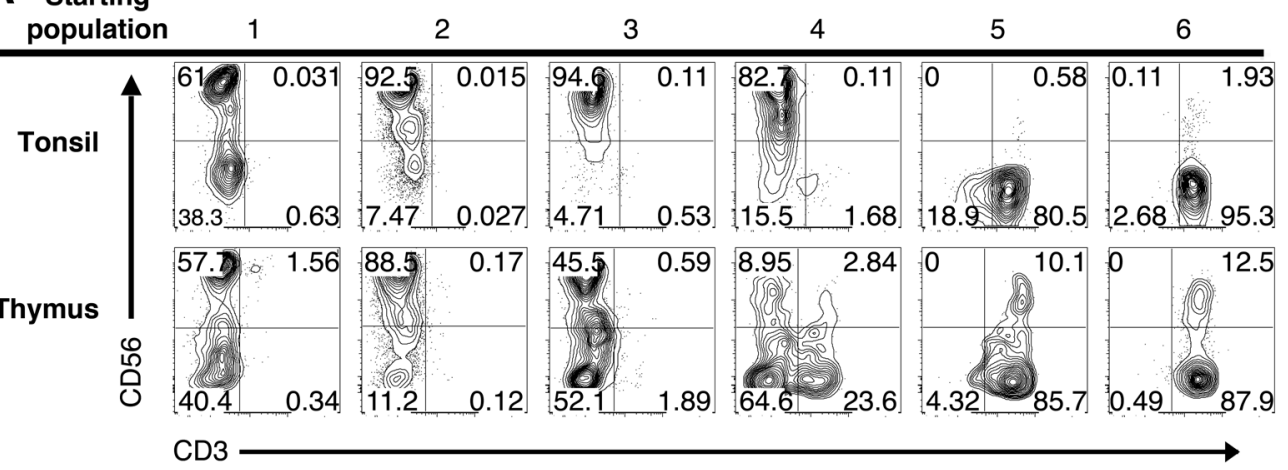

B

Starting

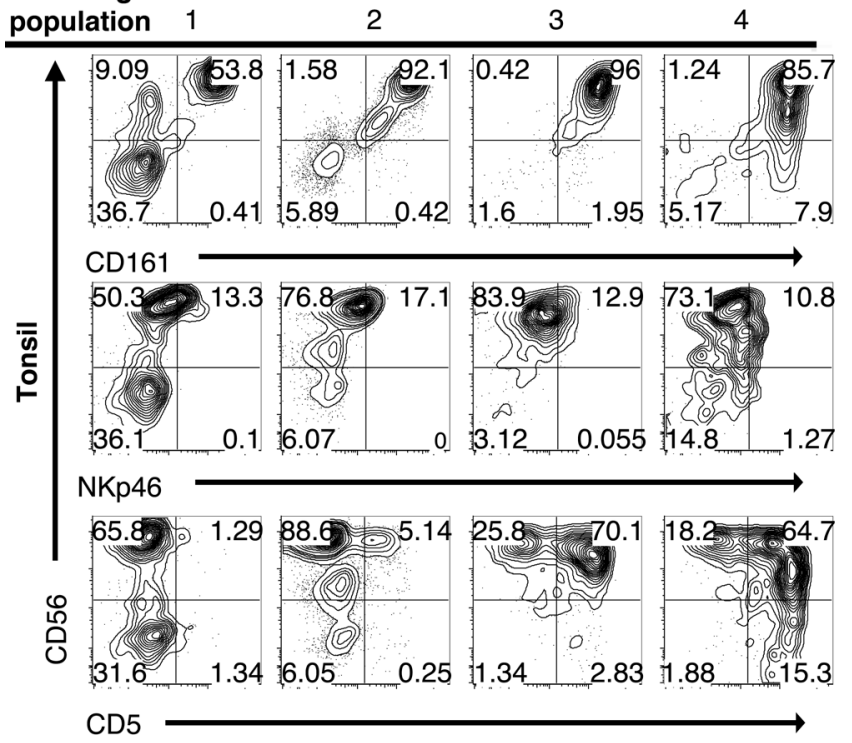

C

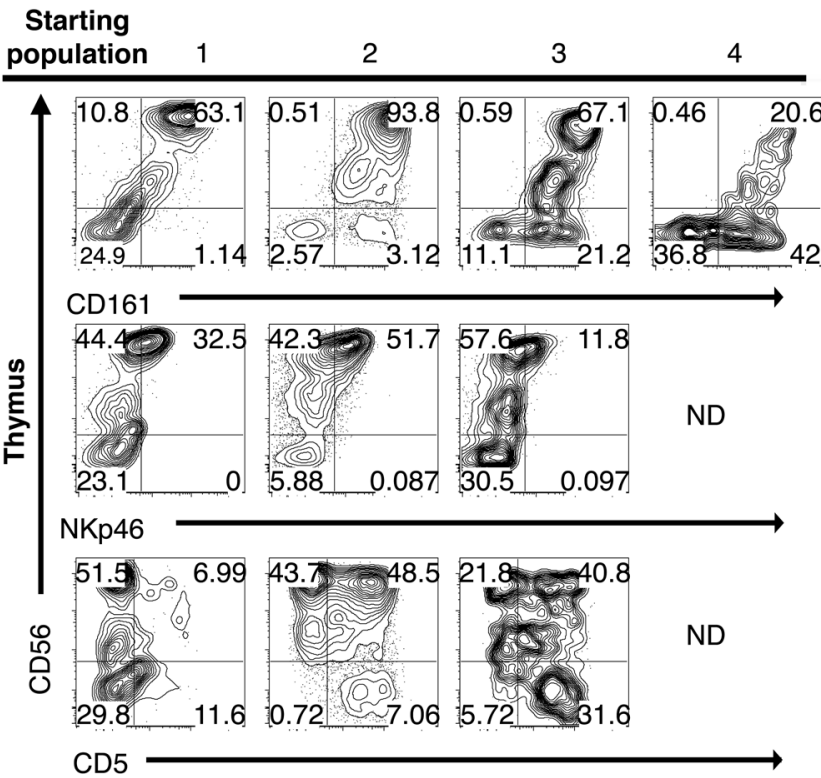

Figure 8

NK cell differentiation potential of putative extrathymic T cell precursors in the human tonsil. (A) Tonsil and thymus cells were sorted as described in Figure 5A. Sorted cells were cultured on OP9-GFP cells and cultured with FL, KL, IL-3, IL-7, and IL-15 for 18 to 19 days. Harvested cells were gated on GFP-CD45+ events and analyzed for expression of CD3 and CD56. (B and C) GFP-CD45+ progeny from populations 1-4 were gated on CD3- events and analyzed for expression of CD56, CD161, NKp46, and CD5. CD3, CD56, CD161, and CD5 data are representative of independent experiments performed with 3 tonsil or 5 thymus donors. NKp46 data are representative of 2 experiments performed with tonsil donors or 3 experiments performed with thymic donors. No data (ND) are available for NKp46 or CD5 expression on progeny of thymic population 4 cells, due to the low numbers of harvested cells. All dot plots and gate frequencies are from a representative experiment. Numbers within each quadrant represent the percentage of events falling within that gate for the representative experiment shown.

It is intriguing to think of a scenario in which both the thymus and tonsil are seeded by the same bone marrow-derived $\mathrm{CD} 34^{+} \mathrm{CD} 38^{\text {dim }} \mathrm{CD}^{2} 5 \mathrm{RA}^{+}$progenitor that gives rise to $\mathrm{NK}$ cells and $\mathrm{T}$ cells in each tissue. However, of the 5 populations identified, we found the most substantial differences when comparing the

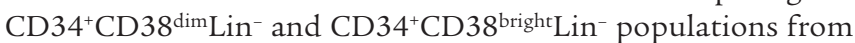
the tonsil and thymus. Specifically, thymic CD $34^{+} \mathrm{CD} 38^{\mathrm{dim} \mathrm{Lin}^{-}}$ cells largely expressed the T cell-associated antigens CD2, CD7, and CD5, whereas tonsillar CD $34^{+} \mathrm{CD} 38^{\text {dim }}$ Lin $^{-}$cells did not. Thus, it is possible that these populations represent distinct progenitors that independently seed the thymus and tonsil. Alternatively, it is possible that the thymus and tonsil are seeded by similar $\mathrm{CD} 34^{+} \mathrm{CD} 38^{\mathrm{dim}}$ progenitors but that the phenotype of these entering cells is rapidly altered by the thymic or tonsillar microenviron- ment, as is seen in the mouse $(39,40)$. As demonstrated in Figure

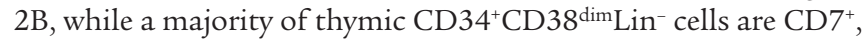
a few lack CD7 (4\%-17\%). Indeed, recent reports suggest that a $\mathrm{CD} 34^{+} \mathrm{CD} 45 \mathrm{RA}^{+} \mathrm{CD} 10^{+} \mathrm{CD}^{-}$cell seeds the thymus after birth, and a CD $34^{+} \mathrm{CD} 45 \mathrm{RA}^{+} \mathrm{CD} 10^{+} \mathrm{CD}^{+}$precursor has yet to be identified in postnatal bone marrow or peripheral blood $(5,6)$. Thus, it is possible that both tissues are seeded by the same circulating CD $34^{+} \mathrm{CD} 38^{\mathrm{dim}} \mathrm{CD} 10^{+} \mathrm{CD} 7-$ hematopoietic progenitor and that this cell is capable of giving rise to downstream $\mathrm{T}$ cell developmental intermediates in each tissue.

Regardless of whether the 2 tissues are seeded by the same progenitor, it is intriguing that $\mathrm{TdT}^{+}$cells within the tonsil aggregate in foci, surrounding fibrous scaffolding. Were the trafficking of $\mathrm{T}$ cell precursors to the tonsil a random event associated with a 
"leaky" thymus, one would assume that the cells would perfuse the tonsil in a scattered arrangement in the interfollicular zone near mature T cells. However, the consistent aggregation of T cell precursors near the fibrous regions of the tonsil suggests that this space serves a unique anatomical function in supporting extrathymic $\mathrm{T}$ cell precursor homing and/or maturation. This hypothesis is further supported by the identification of Notch ligands, which are required for complete $T$ cell differentiation, within the same regions of the human tonsil.

The capsule of the tonsil is highly invaginated into crypts, which create a large surface area important for foreign antigen exposure. Thus, the localization of $\mathrm{T}$ cell precursors to this fibrous region may play a role in mucosal immunity. Alternatively, the thymus is segregated to support different phases of thymocyte development in anatomically distinct microenvironments (41-44), and our finding of tonsillar CD1 $\mathrm{a}^{+} \mathrm{TdT}^{+}$cells near the fibrous scaffolding, but not in the T cell-rich interfollicular zones, suggests that perhaps extrathymic $T$ cell development in the tonsil is also anatomically divided to provide the proper microenvironment for each phase of maturation. In the thymus, the least mature progenitors enter the thymus at the junction between the outer cortex and the inner medulla. These cells migrate outward until they reach the subcapsular zone, which marks the division between the fibrous thymic capsule and the cortex, and then they travel inward toward the medulla to complete differentiation $(43,44)$. Future studies should investigate whether the microenvironment of the tonsillar fibrous scaffold is analogous to the subcapsular zone of the thymus, in terms of supporting $\mathrm{T}$ cell development, or whether it provides a unique signal directing the homing of extrathymic precursors to this region of the tonsil.

This report also provides evidence for the expression of key genes involved in TCR rearrangement within these tonsillar populations. Specifically, we found that populations 2-5 express mRNA for RAG1, which is necessary for initiation of TCR rearrangement (45), and for PTCRA, which is a molecular indicator that successful TCR $\beta$ rearrangement has occurred (3). The expression of these 2 genes, along with $\mathrm{TdT}$, suggests that somatic rearrangement of the TCR may occur in the human tonsil.

In 1998 , Spits et al. reported that $\mathrm{CD} 34^{+} \mathrm{CD} 1 \mathrm{a}^{+}$thymocytes generate only small numbers of NK cells (46). Since then it has generally been held that loss of CD34 and acquisition of CD1a are associated with $\mathrm{T}$ cell commitment $(1,46,47)$. Our findings confirm and extend their work in the thymus, in that we found that CD $34^{+} \mathrm{CD} 38^{\mathrm{dim}}, \mathrm{CD} 34^{+} \mathrm{CD} 38^{\text {bright }}$, and $\mathrm{CD} 34^{+} \mathrm{CD} 1 \mathrm{a}^{+}$thymocytes and tonsil cells readily generate NK cells and that tonsillar CD34$\mathrm{CD} 1 \mathrm{a}^{+} \mathrm{CD} 11 \mathrm{c}^{-}$cells also retain $\mathrm{NK}$ cell potential. Furthermore, some $\mathrm{CD}_{56}{ }^{+} \mathrm{CD}^{-} \mathrm{NK}$ cells generated in our ex vivo cultures coexpressed $\mathrm{CD} 5$, and there was a relative increase in $\mathrm{CD}^{2} 6^{+} \mathrm{CD}^{+} \mathrm{CD}^{-}$progeny generated as one progressed from $\mathrm{CD} 34^{+} \mathrm{CD} 38^{\mathrm{dim}} \mathrm{Lin}^{-}$cells to CD $34^{-} \mathrm{CD} 1 \mathrm{a}^{+} \mathrm{CD} 11 \mathrm{c}^{-}$cells. This suggests that the generated NK cells are not merely a result of starting populations that were impure at sorting but that a unique $\mathrm{CD}^{+}$progenitor may be giving rise to the $\mathrm{CD}^{2} 6^{+} \mathrm{CD}^{-}$cells in cultures initiated with the $\mathrm{CD} 34^{+} \mathrm{CD} 1 \mathrm{a}^{+} \mathrm{CD} 11 \mathrm{c}^{-}$ and $\mathrm{CD} 34^{-} \mathrm{CD} 1 \mathrm{a}^{+} \mathrm{CD} 11 \mathrm{c}^{-}$subsets. Our finding that all 4 populations from the tonsil generate $\mathrm{CD} 56^{+} \mathrm{CD}^{-} \mathrm{NK}$ cells at the single cell level as well substantiated these results. It has become evident that the human tonsil is a significant site of NK cell development $(12-14,28-31)$. However, whether or not differentiating CD34+$\mathrm{CD} 1 \mathrm{a}^{+} \mathrm{CD} 11 \mathrm{c}^{-}$cells that also express $\mathrm{TdT}$ contribute to the physiological NK cell differentiation within this tissue remains unclear.
That the tonsil does support $\mathrm{T}$ cell development could have significant clinical and scientific implications. First, the role of tonsillar T cell development in human disease is unknown. That T cells can develop extrathymically in this tissue raises the possibility that the tonsil may actually support the generation of autoreactive $\mathrm{T}$ lymphocytes or even contribute to malignant transformation. Furthermore, the role of extrathymic $\mathrm{T}$ cell development in the tonsil during inflammation should be of future interest. In this study, we have obtained pediatric tonsils from patients undergoing routine tonsillectomy. While it can be presumed that the patients are afebrile at the time of surgery, the possibility that repeat or sustained inflammation contributes to the presence of extrathymic $\mathrm{T}$ cell development should be further explored.

Alternatively, the identification of an extrathymic reservoir of human $T$ cell precursors in normal individuals could suggest clinical opportunities to enhance $\mathrm{T}$ cell regeneration in situations of thymic defect. For example, T cell deficiency is characteristic in patients with poor thymic function due to complete DiGeorge syndrome, chemoablation or radioablation, or surgical thymectomy (48-52). Indeed, the efficient regeneration of viable thymic tissue after total body irradiation for bone marrow transplant continues to be a significant clinical challenge (49). In the future it may be possible to harvest tonsillar $\mathrm{T}$ cell precursors or healthy tonsil stroma via tonsillectomy in order to augment $\mathrm{T}$ cell regeneration after transplant in the same individual. While these possibilities remain speculative at the moment, the identification of a program of extrathymic $\mathrm{T}$ cell development in the human tonsil is a unique finding with potential implications for human health and disease.

\section{Methods}

Human samples. Human tonsils and thymuses were obtained from Nationwide Children's Hospital (Columbus, Ohio, USA). Tonsils were obtained from pediatric patients undergoing tonsillectomies, whereas thymuses were obtained from children undergoing thoracic surgery. Paraffin-embedded adult tonsils and reactive lymph nodes were obtained from the Biospecimen Shared Resource at The Ohio State University, and adult peripheral blood was obtained from the American Red Cross (Columbus, Ohio, USA). Mononuclear cells were obtained from tonsils and thymuses after manual disaggregation and Ficoll-Paque centrifugation. For experiments wherein tonsillar cells were enriched for CD34-expressing cells only, total cells were depleted of CD19+ and $\mathrm{CD}^{+}$ cells by magnetic depletion and were enriched for $\mathrm{CD} 34^{+}$cells using an indirect CD34 Selection Kit (Miltenyi Biotec). For experiments in which tonsillar cells were enriched for $\mathrm{CD} 1 \mathrm{a}^{+}$cells only, total cells were depleted of $\mathrm{CD} 19^{+}$cells and then magnetically enriched for CD1a-expressing cells (CD1a magnetic beads, Miltenyi Biotec). To simultaneously enrich for CD34- and CD1a-expressing tonsillar cells, CD19-depleted mononuclear cells were subjected to positive selection using the indirect CD34 Selection Kit (Miltenyi Biotec) and CD1a magnetic beads (Miltenyi Biotec) concurrently. To isolate thymic T cell progenitors, total thymic cells were subjected to positive CD34 selection using the indirect CD34 Isolation Kit (Miltenyi Biotec).

Flow cytometry and cell sorting. Antibodies used for flow cytometry were purchased from BD Biosciences, except those for CD56, CD1a, CD127, Nkp46, CD16, and CD161-PE (all from Beckman Coulter) and those for CD161-APC, CD161-FITC, CD11c-FITC, and BDCA-2 (all from Miltenyi Biotec). Intracellular staining for $\mathrm{TdT}$ and $\mathrm{icCD} 3 \varepsilon$ was performed after surface staining using the BD Cytofix/Cytoperm Plus Kit (BD). Flow cytometry was performed on a FACSVantage (BD) or LSR II (BD), and data were 
analyzed using FlowJo software (Treestar Inc). Cell sorting was performed on a FACSAria (BD). The complete gating strategy and a representative purity assessment are shown in Supplemental Figure 2. Purities of sorted populations were routinely more than $95 \%$ pure.

Immunohistochemistry. Immunohistochemistry was performed as described previously $(12,31,53)$ using the UltraView Universal system (Ventana Medical). Anti-TdT (1:100), $\alpha$-CD1a (1:10), $\alpha$-CD34 (1:100), $\alpha$-CD11c (1:100), $\alpha$-DL1 (1:300), and $\alpha$-DL4 (1:300) were purchased from Abcam, and $\alpha$-Rag1 (1:10) was purchased from Santa Cruz Biotechnology Inc. For immunohistochemistry involving $\alpha$-DL1 and $\alpha$-DL4, antigen retrieval was performed for 30 minutes prior to staining. For immunohistochemistry involving $\alpha$-Rag1, antigen retrieval was performed for 30 minutes, along with digestion in Ventana Protease 1 (1:100) for 4 minutes. Images were obtained using a DP 12 camera, a BX50 microscope, and UPLANF1 objectives (Olympus). DAB- and fast-red-stained sections were digitally converted to fluorescent green and red, respectively, using the Nuance FX system (Cambridge Research \& Instrumentation).

Differentiation assays. Cultures were performed in $\alpha$-MEM plus L-glutamine (Gibco) supplemented with $20 \%$ fetal bovine serum and penicillin G plus streptomycin ( $100 \mu \mathrm{g} / \mathrm{ml}$; Gibco), with 500-5,000 cells per well. Medium was supplemented with the following cytokines as indicated: human recombinant FL (100 ng/ml; Miltenyi Biotec), KL (100 ng/ml; Amgen), IL-3 and IL-7 (10 ng/ml; Miltenyi Biotec), and IL-15 (1 nM; Miltenyi Biotec). $\mathrm{T}$ cell differentiation assays were performed as described previously $(13,24)$ on OP9-DL1 cells (a gift from J.C. Zúñiga-Pflücker, University of Toronto, Toronto, Ontario, Canada) with IL-7 and FL. NK cell differentiation assays were performed on OP9 cells (a gift from J.C. Zúñiga-Pflücker) with FL, KL, IL-7, IL-3, and IL-15. For single cell cultures, individual cells from populations 1-4 of the human tonsil were sorted directly into 59 to 60 wells containing OP9-DL1 cells, FL, IL-7, and IL-15 for 14 days. Medium was changed every 4 to 5 days.

Real-time RT-PCR. Tonsillar populations 1-6 were sorted from 8 tonsil donors, as shown in Figure $5 \mathrm{~A}$ and Supplemental Figure 2. From these, we generated 2 pools for each population, with each pool containing cells from 4 of the 8 donors and approximately 3,500 cells. 5,000 cells from populations 1-6 were sorted from 2 thymus donors for comparison. RNA was extracted using the RNeasy Micro Kit (Qiagen), and real-time RT-PCR was performed as previously described (30), using ABI TaqMan primer/probe sets for PTCRA (probe Hs00300125_m1), RAG1 (probe Hs00172121_m1), BCL2L1 (probe Hs00236329_m1), and THPOK (probe_Hs01035470_m1). Expression levels were normalized to $18 \mathrm{~S}$ expression and were analyzed using the comparative $\Delta \delta C T$ method (54).

Statistics. To investigate whether age or gender correlates with the percentage of $\mathrm{CD} 34^{+} \mathrm{CD} 1 \mathrm{a}^{+} \mathrm{CD} 11 \mathrm{c}^{-}$cells, a Spearman correlation and a 2sample, 2-tailed $t$ test were used. In reporting the percentages of $\mathrm{CD}^{+}$ $\mathrm{T}$ cells generated in $\mathrm{T}$ cell differentiation assays, the mean percentage $\pm \mathrm{SEM}$ of $\mathrm{GFP}^{-} \mathrm{CD} 45^{+}$cells was listed. For comparison of $\mathrm{CD}^{+}$cells generated from populations in the human thymus and those from the tonsil, the linear mixed effects models were used to take account of the correlation among observations from the same donor. After Holm's adjustment for multiple comparisons, $P$ values of equal to or less than 0.005 were considered significant.

Study approval. Tonsillar, thymic, and peripheral blood samples were obtained with approval of these experiments from The Ohio State University Comprehensive Cancer Center Institutional Review Board. As all human samples were obtained as deidentified tissue, informed consent was not required.

\section{Acknowledgments}

This work was supported by NCI grants (CA95426 and CA68458). The authors acknowledge the use of the biorepository of Nationwide Children's Hospital and the Biostatistics, Flow Cytometry, Microscopy, Leukemia Tissue Bank, Biorepository, and Biospecimen Shared Resources of The Ohio State University Comprehensive Cancer Center. We thank Ventana Medical Systems for providing reagents for the immunohistochemistry.

Received for publication December 16, 2010, and accepted in revised form January 11, 2012.

Address correspondence to: Michael A. Caligiuri, 521B James Cancer Hospital, 300 W. 10th Ave., Columbus, Ohio 43210, USA. Phone: 614.293.7521; Fax: 614.293.3132; E-mail: Michael. Caligiuri@osumc.edu.
1. Blom B, Spits H. Development of human lymphoid cells. Annu Rev Immunol. 2006;24:287-320.

2. Staal FJ, Weerkamp F, Langerak AW, Hendriks RW, Clevers HC. Transcriptional control of T lymphocyte differentiation. Stem Cells. 2001;19(3):165-179.

3. Dik WA, et al. New insights on human T cell development by quantitative $T$ cell receptor gene rearrangement studies and gene expression profiling. J Exp Med. 2005;201(11):1715-1723.

4. Klein F, et al. T lymphoid differentiation in human bone marrow. Proc Natl Acad Sci U S A. 2003;100(11):6747-6752.

5. Doulatov S, Notta F, Eppert K, Nguyen LT, Ohashi PS, Dick JE. Revised map of the human progenitor hierarchy shows the origin of macrophages and dendritic cells in early lymphoid development. Nat Immunol. 2010;11(7):585-593.

6. Six EM, et al. A human postnatal lymphoid progenitor capable of circulating and seeding the thymus. J Exp Med. 2007;204(13):3085-3093.

7. Williams $A M$, et al. Intestinal alpha beta $T$ cells differentiate and rearrange antigen receptor genes in situ in the human infant. $J$ Immunol. 2004;173(12):7190-7199.

8. Strauchen JA, Miller LK. Terminal deoxynucleotidyl transferase-positive cells in human tonsils. Am J Clin Pathol. 2001;116(1):12-16.

9. Strauchen JA, Miller LK. Lymphoid progenitor cells in human tonsils. Int J Surg Pathol. 2003;11(1):21-24.
10. Sening W, Lisner R, Niedobitek G. Rare detection of phenotypically immature lymphocytes in Hashimoto thyroiditis and rheumatoid arthritis. J Autoimmun. 2004;22(2):147-152

11. Meru N, Jung A, Baumann I, Niedobitek G. Expression of the recombination-activating genes in extrafollicular lymphocytes but no apparent reinduction in germinal center reactions in human tonsils. Blood. 2002;99(2):531-537.

12. Freud AG, et al. A human CD34(+) subset resides in lymph nodes and differentiates into CD56bright natural killer cells. Immunity. 2005;22(3):295-304.

13. Freud AG, et al. Evidence for discrete stages of human natural killer cell differentiation in vivo. J Exp Med. 2006;203(4):1033-1043.

14. Freud AG, Caligiuri MA. Human natural killer cell development. Immunol Rev. 2006;214:56-72.

15. Hao QL, Shah AJ, Thiemann FT, Smogorzewska EM, Crooks GM. A functional comparison of CD34 + CD38- cells in cord blood and bone marrow. Blood. 1995;86(10):3745-3753.

16. Hao QL, Zhu J, Price MA, Payne KJ, Barsky LW, Crooks GM. Identification of a novel, human multilymphoid progenitor in cord blood. Blood. 2001;97(12):3683-3690.

17. Res $\mathrm{P}$, et al. CD34+CD38dim cells in the human thymus can differentiate into $\mathrm{T}$, natural killer, and dendritic cells but are distinct from pluripotent stem cells. Blood. 1996;87(12):5196-5206.
18. Indrasingh I, Chandi G, Jeyaseelan L, Vettivel S, Chandi SM. Quantitative analysis of CD1a (T6) positive Langerhans cells in human tonsil epithelium. Ann Anat. 1999;181(6):567-572.

19. Liu YJ. Dendritic cell subsets and lineages, and their functions in innate and adaptive immunity. Cell. 2001;106(3):259-262.

20. Nascimbeni M, Shin EC, Chiriboga L, Kleiner DE, Rehermann B. Peripheral CD4(+)CD8(+) T cells are differentiated effector memory cells with antiviral functions. Blood. 2004;104(2):478-486.

21. Boise LH, et al. bcl-x, a bcl-2-related gene that functions as a dominant regulator of apoptotic cell death. Cell. 1993;74(4):597-608.

22. Chao DT, Korsmeyer SJ. BCL-XL-regulated apoptosis in $\mathrm{T}$ cell development. Int Immunol. 1997;9(9):1375-1384.

23. Tokunaga $\mathrm{T}$, et al. Regulation of Th-POK and Runx3 in T cell development in human thymoma. Autoimmunity. 2009;42(8):653-660

24. La Motte-Mohs RN, Herer E, Zuniga-Pflucker JC. Induction of T-cell development from human cord blood hematopoietic stem cells by Delta-like 1 in vitro. Blood. 2005;105(4):1431-1439.

25. De Smedt M, et al. Active form of Notch imposes $\mathrm{T}$ cell fate in human progenitor cells. J Immunol. 2002;169(6):3021-3029.

26. Schmitt TM, Ciofani M, Petrie HT, Zuniga-Pflucker JC. Maintenance of T cell specification and differ- 
entiation requires recurrent notch receptor-ligand interactions. J Exp Med. 2004;200(4):469-479.

27. Van de Walle I, et al. An early decrease in Notch activation is required for human TCR-alphabeta lineage differentiation at the expense of TCR-gammadelta T cells. Blood. 2009;113(13):2988-2998.

28. Cupedo T, et al. Human fetal lymphoid tissueinducer cells are interleukin 17-producing precursors to RORC+CD127+ natural killer-like cells. Nat Immunol. 2009;10(1):66-74.

29. Crellin NK, Trifari S, Kaplan CD, Cupedo T, Spits H. Human NKp44+IL-22+ cells and LTi-like cells constitute a stable RORC+ lineage distinct from conventional natural killer cells. J Exp Med. 2010;207(2):281-290.

30. Hughes $\mathrm{T}$, et al. Interleukin-1beta selectively expands and sustains interleukin-22+ immature human natural killer cells in secondary lymphoid tissue. Immunity. 2010;32(6):803-814.

31. Hughes T, et al. Stage three immature human natural killer cells found in secondary lymphoid tissue constitutively and selectively express the TH17 cytokine interleukin-22. Blood. 2009; 113(17):4008-4010.

32. Oida $\mathrm{T}$, et al. Role of gut cryptopatches in early extrathymic maturation of intestinal intraepithelial T cells. J Immunol. 2000;164(7):3616-3626.

33. Ishikawa H, Saito H, Suzuki K, Oida T, Kanamori Y. New gut associated lymphoid tissue "cryptopatches" breed murine intestinal intraepithelial T cell precursors. Immunol Res. 1999;20(3):243-250.

34. Suzuki K, et al. Gut cryptopatches: direct evidence of extrathymic anatomical sites for intestinal $\mathrm{T}$ lymphopoiesis. Immunity. 2000;13(5):691-702.

35. Guy-Grand D, et al. Extrathymic T cell lymphopoiesis: ontogeny and contribution to gut intraepithelial lymphocytes in athymic and euthymic mice.
J Exp Med. 2003;197(3):333-341.

36. Haddad R, et al. Dynamics of thymus-colonizing cells during human development. Immunity. 2006;24(2):217-230.

37. Hao QL, et al. Human intrathymic lineage commitment is marked by differential CD7 expression: identification of CD7-lympho-myeloid thymic progenitors. Blood. 2008;111(3):1318-1326.

38. Awong G, Herer E, Surh CD, Dick JE, La MotteMohs RN, Zuniga-Pflucker JC. Characterization in vitro and engraftment potential in vivo of human progenitor T cells generated from hematopoietic stem cells. Blood. 2009;114(5):972-982.

39. Krueger A, Garbe AI, von Boehmer H. Phenotypic plasticity of T cell progenitors upon exposure to Notch ligands. J Exp Med. 2006;203(8):1977-1984.

40. Schwarz BA, Sambandam A, Maillard I, Harman BC, Love PE, Bhandoola A. Selective thymus settling regulated by cytokine and chemokine receptors. J Immunol. 2007;178(4):2008-2017.

41. Lind EF, Prockop SE, Porritt HE, Petrie HT. Mapping precursor movement through the postnatal thymus reveals specific microenvironments supporting defined stages of early lymphoid development. J Exp Med. 2001;194(2):127-134.

42. Bousso P, Bhakta NR, Lewis RS, Robey E. Dynamics of thymocyte-stromal cell interactions visualized by two-photon microscopy. Science. 2002;296(5574):1876-1880.

43. Petrie HT, Zuniga-Pflucker JC. Zoned out: functional mapping of stromal signaling microenvironments in the thymus. Annu Rev Immunol. 2007;25:649-679.

44. Klein L, Hinterberger M, Wirnsberger G, Kyewski $B$. Antigen presentation in the thymus for positive selection and central tolerance induction. Nat Rev Immunol. 2009;9(12):833-844.
45. Spanopoulou E, et al. Localization, interaction, and RNA binding properties of the $\mathrm{V}(\mathrm{D}) \mathrm{J}$ recombination-activating proteins RAG1 and RAG2. Immunity. 1995;3(6):715-726.

46. Spits H, et al. Early stages in the development of human $\mathrm{T}$, natural killer and thymic dendritic cells. Immunol Rev. 1998;165:75-86

47. Weerkamp F, et al. Human thymus contains multipotent progenitors with $\mathrm{T} / \mathrm{B}$ lymphoid, myeloid, and erythroid lineage potential. Blood. 2006;107(8):3131-3137.

48. Prelog $\mathrm{M}$, et al. Thymectomy in early childhood: significant alterations of the CD4(+) CD45RA $(+) \operatorname{CD} 62 \mathrm{~L}(+) \mathrm{T}$ cell compartment in later life. Clin Immunol. 2009;130(2):123-132.

49. Hollander GA, Krenger W, Blazar BR. Emerging strategies to boost thymic function. Curr Opin Pharmacol. 2010;10(4):443-453.

50. Markert ML, et al. Transplantation of thymus tissue in complete DiGeorge syndrome. N Engl J Med. 1999;341(16):1180-1189.

51. Fischer A, et al. Naturally occurring primary deficiencies of the immune system. Annu Rev Immunol. 1997;15:93-124.

52. Sauce D, et al. Evidence of premature immune aging in patients thymectomized during early childhood. J Clin Invest. 2009;119(10):3070-3078.

53. Fehniger TA, et al. CD56bright natural killer cells are present in human lymph nodes and are activated by $\mathrm{T}$ cell-derived IL-2: a potential new link between adaptive and innate immunity. Blood. 2003; 101(8):3052-3057.

54. Fehniger TA, et al. Differential cytokine and chemokine gene expression by human NK cells following activation with IL-18 or IL-15 in combination with IL-12: implications for the innate immune response. J Immunol. 1999;162(8):4511-4520. 